Review

\title{
Development of Efficient and Stable Inverted Bulk Heterojunction (BHJ) Solar Cells Using Different Metal Oxide Interfaces
}

\section{Ivan Litzov $^{1} *$ and Christoph J. Brabec ${ }^{1,2}$}

1 Institute of Materials for Electronics and Energy Technology(I-MEET),

Friedrich-Alexander University of Erlangen-Nuremberg, Martensstrasse 7, Erlangen 91058,

Germany; E-Mail: christoph.brabec@ww.uni-erlangen.de

2 Bavarian Center for Applied Energy Research (ZAE Bayern), Haberstrasse 2a,

Erlangen 91058, Germany

* Author to whom correspondence should be addressed; E-Mail: ivan.litzov@ww.uni-erlangen.de;

Tel.: +49-9131-85-27722; Fax: +49-9131-85-28495.

Received: 18 October 2013; in revised form: 2 December 2013 / Accepted: 5 December 2013 /

Published: 10 December 2013

\begin{abstract}
Solution-processed inverted bulk heterojunction (BHJ) solar cells have gained much more attention during the last decade, because of their significantly better environmental stability compared to the normal architecture BHJ solar cells. Transparent metal oxides $\left(\mathrm{MeO}_{x}\right)$ play an important role as the dominant class for solution-processed interface materials in this development, due to their excellent optical transparency, their relatively high electrical conductivity and their tunable work function. This article reviews the advantages and disadvantages of the most common synthesis methods used for the wet chemical preparation of the most relevant $n$-type- and $p$-type-like $\mathrm{MeO}_{x}$ interface materials consisting of binary compounds $\mathrm{A}_{x} \mathrm{~B}_{y}$. Their performance for applications as electron transport/extraction layers (ETL/EEL) and as hole transport/extraction layers (HTL/HEL) in inverted BHJ solar cells will be reviewed and discussed.
\end{abstract}

Keywords: sol-gel methods; metal oxide interfaces; inverted structure; device stability 


\section{Introduction}

Solar cells are considered an ideal technology for renewable power generation, as they directly convert solar energy into electricity without any "green-house" gas emission. Today, still, solar cells based on Si dominate the photovoltaic (PV) market [1]. With the discovery of high conductivity in perylene-iodine complexes in 1954, organic semiconductors have become intensively researched. The unique properties of organic semiconductors, like flexibility, thinness and simple fabrication processes, enable the potential applications for organic solar cells (OSCs) and organic light emitting diodes (OLEDs) [2]. However one of the major breakthroughs in the field of OSC was the discovery of bulk heterojunction (BHJ) composites, resulting in two different prototype architectures: on the one hand, the "normal structure" architecture, traditionally requiring reactive cathode materials, like $\mathrm{Ca}$ or LiF [3-14], and, on the other hand, the "inverted structure" [15-29], allowing one to work with air stable cathode materials, like indium tin oxide (ITO) or Ag. Therefore, inverted architecture BHJ solar cells provide a good strategy for improved air stability. The interface materials play an essential role in designing efficient and stable $\mathrm{BHJ}$ solar cells. $\mathrm{MeO}_{x}$ have been reported not only as an electron/hole transport layer (ETL/HTL) or an electron/hole extraction layer (EEL/HEL), but also as an electrical contact to a less air-sensitive high work function metal, e.g., Ag or Al (Au) [22-25].

In general, $\mathrm{MeO}_{x}$ have good optical transparency and sufficient electrical conductivity. Today, the focus of scientists is on the processing of highly transparent and conductive thin films based on n-type- and p-type-like semiconductor metal oxides [23,30-32]. Most of these $\mathrm{MeO}_{x}$ are binary compounds, like $\mathrm{ZnO}, \mathrm{TiO}_{2}, \mathrm{SnO}_{2}, \mathrm{In}_{2} \mathrm{O}_{3}, \mathrm{MoO}_{3}, \mathrm{WO}_{3}$ or $\mathrm{V}_{2} \mathrm{O}_{5}$, consisting of one metallic element. One advantage of using binary compounds as interface materials is that their chemical composition in film depositions is relatively easy to control, compared to the ternary compounds and multicomponent oxides [33].

Metal oxides can be prepared in various sizes and geometries, but one of the greatest challenges remains the precise control of the particle size, shape, crystalline structure and processing properties.

A great number of synthesis methods were tested over the last several years [34-64], which all allow access to $\mathrm{MeO}_{x}$ nanomaterials with uniform crystal structure, form and varied composition. The liquid phase synthesis methods are more versatile with regards to controlling the structural and morphological properties of the products, compared to, for example, the gas phase processes [39]. Potential pathways in liquid phase syntheses include a precipitation reaction, an aqueous or non-hydrolytic sol-gel process [38,41,56,57,61] and hydrothermal [49,59] or solvothermal methods [53,58]. The synthesis of the desired metal oxide nanoparticles requires, in some cases, a combination of these techniques. Aqueous sol-gel methods were used for decades for the production of highly monodisperse colloids, despite their limitations concerning the low crystallinity. Additionally, the aqueous synthesis pathways are very demanding, due to the higher reactivity of metals in the starting precursors and the double functionality of water as the solvent and ligand. The slightest variations of reaction conditions may leads to different particle morphologies and, therefore, complicate the use of these synthesis routes for industry applications [57].

In this review, we will summarize the most frequently published chemical methods for the synthesis of transition metal oxides. A focus is placed on the classical sol-gel methods (precipitation reactions) [34,35,37,38,40,41,43-45,52,64] and the so-called non-hydrolytic sol-gel methods $[49,53,56,57,61]$ at moderate temperatures without surfactants. In the second part of this 
review, we will discuss the application of the corresponding $\mathrm{MeO}_{x}$ as interface layers in the inverted BHJ organic solar cells.

\section{Comparison between the Classical Sol-Gel Method (Precipitation Reactions) and the} Non-hydrolytic Sol-Gel Method

In this section, we will discuss the principles of the sol-gel process, with particular emphasis on its potential for transition metal oxide $\left(\mathrm{MeO}_{x}\right)$ synthesis via the classical sol-gel method (precipitation reactions) and the non-hydrolytic sol-gel method.

In general, the sol-gel process consists of the following steps: (1) preparation of a homogeneous solution, either by dissolution of the metal organic precursors in an organic solvent or by dissolution of inorganic salts in an organic solvent or water; (2) conversion of the homogeneous solution into a sol by treatment with a suitable reagent (generally base); (3) aging; (4) shaping; and (5) thermal treatment or sintering [65] (Figure 1).

Figure 1. Various sol-gel options to control the final morphology of the different product.

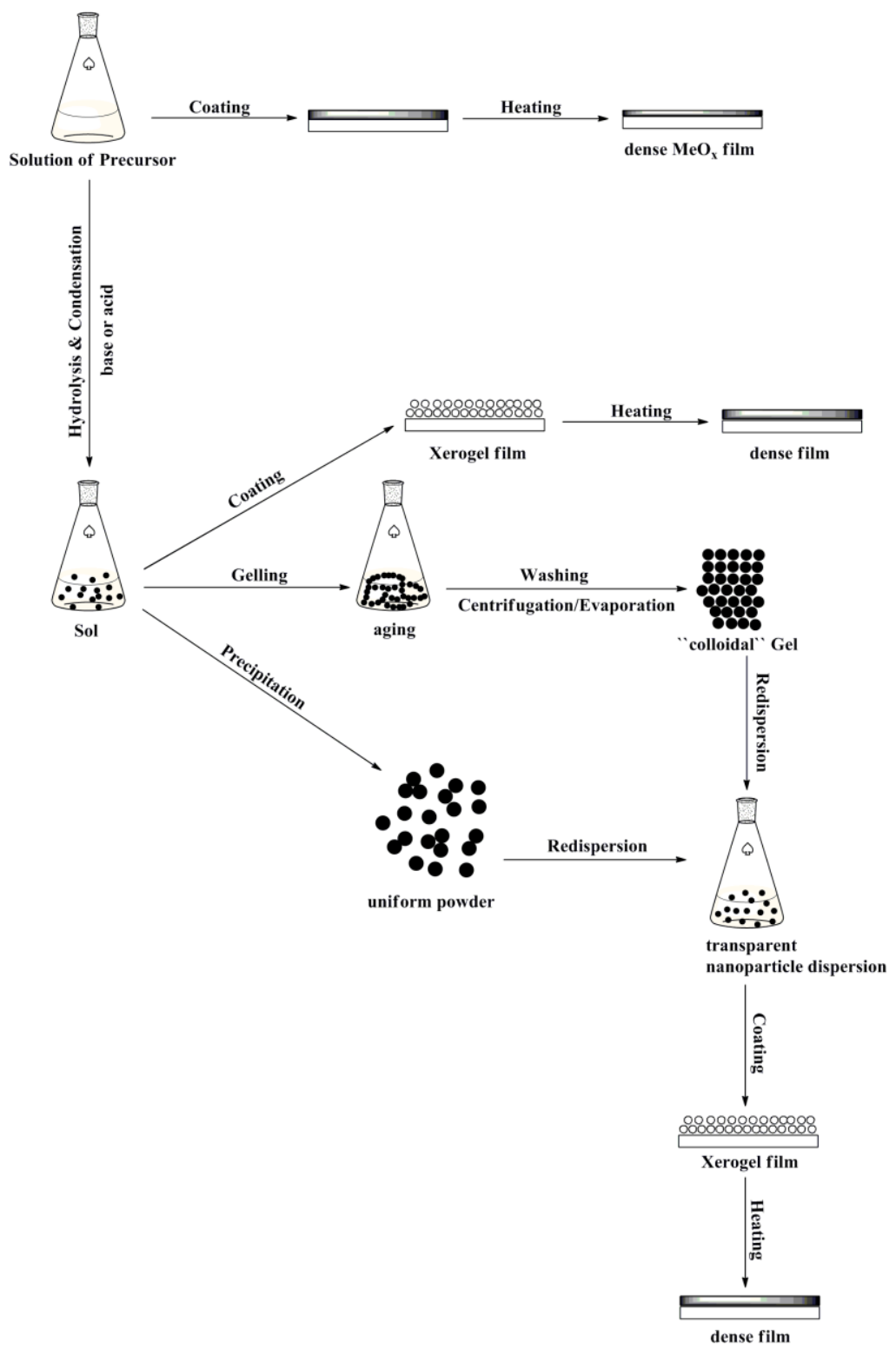




\subsection{Classical Sol-Gel Method}

The classical sol-gel method (precipitation reactions) is the conversion of a precursor solution into an inorganic solid via inorganic polymerization reactions induced by strong bases $(\mathrm{KOH} ; \mathrm{NaOH}$; $\mathrm{LiOH} \cdot \mathrm{H}_{2} \mathrm{O} ; \mathrm{LiOH}$ ). The starting compound is either an inorganic metal salt (chloride; nitrate; sulfate, and so on) or a metal organic compound, such as acetate [Equation (1)] [65]. However, this method has several disadvantages in which the formation of condensed species from alcoholic solutions of inorganic salts or metal organic compound occurs by adjusting the $\mathrm{pH}$, by increasing the temperature or by changing the oxidation state. The chemistry of transition metal ions is complicated, because of the formation of a large number of oligomeric species. The nature of these species depends on the counter anions, which are able to coordinate the metal ion and initiate new molecular precursors with different chemical reactivity towards hydrolysis and condensation. These counter ions can influence the morphology, the structure and even the chemical composition of the resulting solid phase. Furthermore, the removal of these anions from the final metal oxide product is frequently a big challenge [65].

$$
\mathrm{MX}_{2}+2 \mathrm{BH} \rightarrow \mathrm{MO}_{(\mathrm{S})}+2 \mathrm{~B}^{+}+2 \mathrm{X}^{-}+\mathrm{H}_{2} \mathrm{O}
$$

where $\mathrm{X}=\left(\mathrm{CH}_{3} \mathrm{COO}^{-} ; \mathrm{Cl}^{-} ; \mathrm{NO}_{3}{ }^{-}\right) ; \mathrm{B}=\left(\mathrm{Na}^{+} ; \mathrm{K}^{+} ; \mathrm{Li}^{+}\right)$; solvent: methanol; ethanol; iso-propanol. This equation is the inorganic polymerization reactions induced by a base.

These challenges can be addressed by using metal organic compounds (e.g., metal alkoxides), which can be dissolved in organic solvents $\left(\mathrm{sMeO}_{x}\right)$. These precursor solutions provide highly homogeneous mixtures and can be directly deposited and thermally converted into the corresponding oxide (See Figure 1).

\subsection{Non-Hydrolytic Sol-Gel Method}

The main problem of the classical sol-gel method based on hydrolysis and condensation of molecular precursors is the control over the reaction rate. For most transition metal oxide precursors, these reactions are very fast, resulting in the loss of morphological and also structural control over the final material composition. One possibility to decrease and to adjust the reactivity of the precursors is the use of organic additives, like amines, $\beta$-diketones, carboxylic acids or functional alcohols, which act as chelating ligands and modify the reactivity of the precursors [65]. Nevertheless, general predictions for the various reaction paths between the central metal ions with different ligands are still under intense research.

In the non-hydrolytic sol-gel process, divided into surfactant-directed and solvent-controlled approaches, the transformation of the precursor takes place in an organic solvent under exclusion of water or a base. Interestingly, independent of whether surfactants are used or not, only five distinct condensation reaction mechanisms partly explain the formation of the metal-oxygen-metal (M-O-M) bond. These condensation steps are: (1) alkyl halide elimination; (2) ether elimination; (3) ester and amide elimination; (4) $\mathrm{C}-\mathrm{C}$ coupling of benzylic alcohols and alkoxide molecules; and (5) aldol/ketimine condensation [57,61].

According to Vioux [36], in non-hydrolytic procedures using hydrated metal oxide precursors and/or water $\left(\mathrm{H}_{2} \mathrm{O}\right)$ produced in situ, a hydrolytic reaction pathway cannot be excluded. Among the 
five non-hydrolytic sol-gel condensation steps mentioned above, the following specific reaction paths are of high relevance for the metal oxides: (1) non-hydrolytic hydroxylation reactions; and (2) aprotic condensation reactions.

Thermal decomposition of metal alkoxide(carboxylate) precursors is a non-hydrolytic hydroxylation reaction, where hydroxyl groups are produced via a cyclic elimination mechanism with the liberation of alkene (Scheme 1) [36].

Scheme 1. Thermal decomposition of metal alkoxide(carboxylate) precursors.

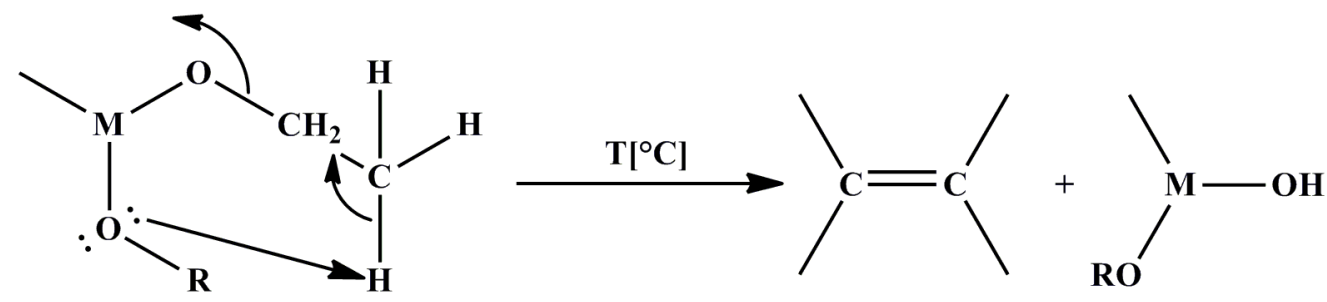

This reaction type is more relevant to MOCVD (metal-organic chemical vapor deposition), but it is probable that it involves the thermal degradation of residual alkoxy groups during the calcinations of non-hydrolytic gels into oxides [36].

Other reactions between primary, secondary and tertiary alcohols and also benzylic alcohols with halides involve, initially, the coordination of a lone pair of electrons of an alcoholic oxygen atom to the metal center, followed by the cleavage of either the hydroxyl or alkoxyl group (Scheme 2). Electron-donor substituent groups in the alkyl radical direct the process to hydroxylation (liberation of $\mathrm{RCl}$ ) by favoring the nucleophilic attack of chloride on the carbon group, due to its increased cationic character $\left(\mathrm{S}_{\mathrm{N}}{ }^{1}\right.$ mechanism) [36].

Scheme 2. Reaction of different types of alcohols with halides.

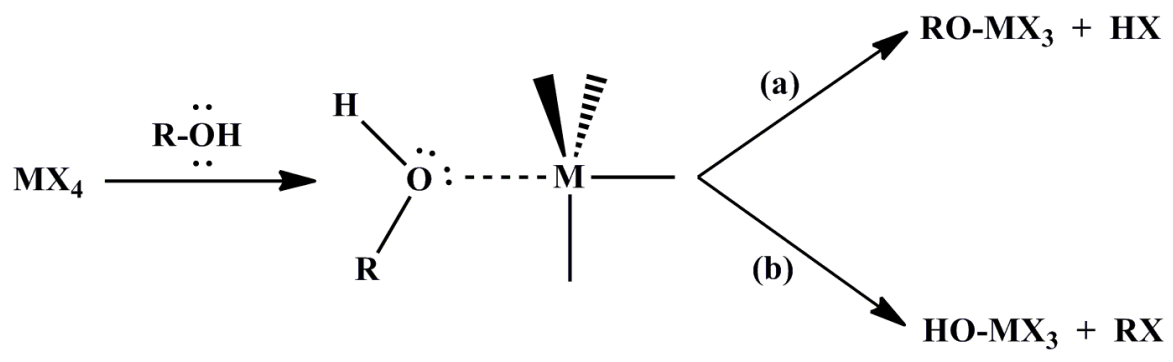

Aprotic condensation reactions excluding hydroxyl groups are attractive non-hydrolytic methods for the formation of an oxo-bridge normally generated between two different functional groups bonded to two different metal centers by eliminating small organic molecules (Scheme 3) [36].

The advantages of the non-hydrolytic sol-gel method are a direct consequence of the manifold role of the organic components in the reaction system (solvent, organic ligand of the precursor molecule or in situ formed organic condensation products). On the one hand, they act as an oxygen-supplier for oxide formation and strongly determine the particle size and shape, as well as the surface properties, due to their coordination properties, and on the other hand, the moderate reactivity of the oxygen-carbon bond generally results in slower reaction rates. Another important point is the fact that the chemistry of the oxygen-carbon bond is well-known in the field of organic chemistry [65]. 
Scheme 3. Aprotic condensation reactions.
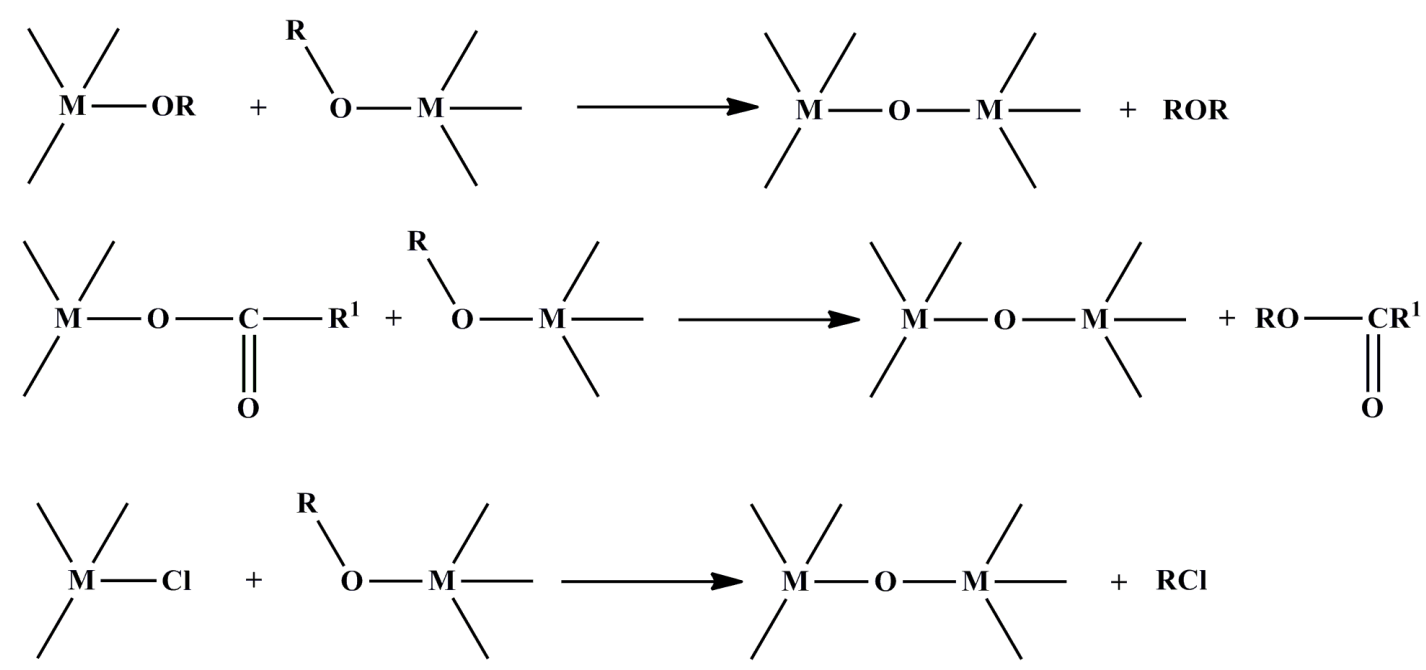

Summarizing this section, it is important to note that not all wet chemical reactions follow the definition of sol-gel chemistry, and the complex interaction principles on the molecular level have frequently been not fully clarified $[36,65]$.

\section{Synthesis of n-Type- and p-Type-Like Transition Metal Oxides by Wet Chemical Methods}

The sol-gel method for $\mathrm{MeO}_{x}$ is attractive, because it is a low cost atmospheric process, and it can be easily adapted to industrial use. One important argument for using sol-gel synthesis methods is their compatibility for thin film formation from cross-linked liquid chemical precursors by doctor blading, spin-coating, dip-coating or drop-coating. The sol-gel process is a widely accepted method for large-scale architectural coatings. The key to a successful sol-gel method is in the preparation of a stable solution for the deposition.

\subsection{Zinc Oxide $(\mathrm{ZnO})$}

Zink oxide $(\mathrm{ZnO})$ is an $n$-type, direct, wide band gap $\left(E_{\mathrm{g}}=3.37 \mathrm{eV}\right)$ and non-toxic semiconductor material with attractive electrical $[33,66]$, chemical $[44,45,48,52]$, physical $[51,52,67]$ and magnetic [47] properties. The crystal structures shared by $\mathrm{ZnO}$ are wurtzite, zinc blende and rock salt. Under ambient conditions, the thermodynamically stable phase has wurtzite symmetry. The zinc blende $\mathrm{ZnO}$ structure can be stabilized only by growth on cubic substrates, and the rock salt, or Rochelle salt $(\mathrm{NaCl})$, structure may be obtained at relatively high pressures [68]. In recent years, $\mathrm{ZnO}$ received considerable interest of the scientific community, due to its prospective use as a printable transparent conductive electrode for photovoltaics. Here, the focus will be more on the chemical synthesis of spherical $\mathrm{ZnO}$ nanoparticles via the classical sol-gel method and on the preparation of $\mathrm{Al}^{3+}$ doped $\mathrm{ZnO}$ precursor solutions (sAZO).

\subsubsection{Synthesis of Colloidal ZnO Nanoparticles (NPs)}

In general, $\mathrm{ZnO}$ based on nanocolloids or nanopowders was synthesized by modifying and adapting synthetic routes developed by Bahnemann et al. [34], Spanhel et al. [35,52], Meulenkamp [37] or 
Pacholski et al. [44]. Depending on the experimental conditions, different types of $\mathrm{ZnO}$ nanostructures, such as particles [34,35,37,45] or rods [44], are observed.

The dominant zinc sources are zinc acetate dihydrate, zinc acetate, zinc nitrate and zinc chloride, which are dissolved in alcoholic or other organic solvents as starting solutions. A basic solution containing $\mathrm{NaOH}, \mathrm{KOH}, \mathrm{LiOH} \mathrm{H}_{2} \mathrm{O}$ or $\mathrm{LiOH}$ is typically added under vigorous stirring [69], where refluxing of the mixture is optional. It is believed that the formation of colloidal $\mathrm{ZnO}$ follows several reaction steps, of which, the last is the transformation of zinc hydroxide to zinc oxide under basic solution conditions. In the presence of acetate ions in the basic solution, the precursors of $\mathrm{ZnO}$ are reported to be (1) tetrahedral oxy-acetate $\mathrm{Zn}_{4} \mathrm{O}(\mathrm{Ac})_{6}$ [52], also called "basic zinc acetate", and its larger self-similar homologue, $\mathrm{Zn}_{10} \mathrm{O}_{4}(\mathrm{Ac})_{12}$ [52]; (2) ethoxy acetate (EtOZnAc) ${ }_{n}$, forming wire-like nanostructures; and (3) the hydroxyl-acetate $\mathrm{Zn}_{5}(\mathrm{OH})_{8}(\mathrm{Ac})_{2} \cdot 2 \mathrm{H}_{2} \mathrm{O}$ monomer of lamellar sheet compounds, also known as "hydroxy double salt" (Zn-HDS) [52]. It was found that $\mathrm{Zn}_{4} \mathrm{O}(\mathrm{Ac})_{6}$ clusters are formed in ethanol and 1-propanol at temperatures above $50{ }^{\circ} \mathrm{C}$ by prolonged refluxing of alcoholic zinc acetate dihydrate (ZAH) salt solutions, and the heating step can be described by the following overall reaction (Equation (2)) [52,70].

$$
4 \mathrm{Zn}(\mathrm{Ac})_{2} \cdot 2 \mathrm{H}_{2} \mathrm{O} \rightarrow \mathrm{Zn}_{4} \mathrm{O}(\mathrm{Ac})_{6}+7 \mathrm{H}_{2} \mathrm{O}+2 \mathrm{HAc}
$$

According to Briois et al. [70], the formation of Zn-HDS is now recognized for reactions carried out with the addition of water. The following reactions are proposed (Equations 3-5) [52,70]:

$$
\begin{gathered}
\mathrm{Zn}_{4} \mathrm{O}(\mathrm{Ac})_{6}+\mathrm{Zn}(\mathrm{Ac})_{2}+9 \mathrm{H}_{2} \mathrm{O} \rightarrow \mathrm{Zn}_{5}(\mathrm{OH})_{8}(\mathrm{Ac})_{2}\left(\mathrm{H}_{2} \mathrm{O}_{2}\right)+6 \mathrm{HAc} \\
\mathrm{Zn}_{10} \mathrm{O}_{4}(\mathrm{Ac})_{12}+16 \mathrm{H}_{2} \mathrm{O} \rightarrow 2 \mathrm{Zn}_{5}(\mathrm{OH})_{8}(\mathrm{Ac})_{2}\left(\mathrm{H}_{2} \mathrm{O}\right)+8 \mathrm{HAc} \\
\mathrm{Zn}_{10} \mathrm{O}_{4}(\mathrm{Ac})_{12}+8 \mathrm{H}_{2} \mathrm{O}+8 \mathrm{OH}^{-} \rightarrow 2 \mathrm{Zn}_{5}(\mathrm{OH})_{8}(\mathrm{Ac})_{2}\left(\mathrm{H}_{2} \mathrm{O}_{2}\right)+8 \mathrm{Ac}^{-}
\end{gathered}
$$

In fact, real-time monitoring of chemical reactions taking place in zinc acetate-based precursor solutions reveals a complex chemistry, where the sequences of the formation of $\mathrm{ZnO}$ and $\mathrm{Zn}-\mathrm{HDS}$ are strongly dependent on the oxygen donor source used to initiate the hydrolysis (Briois et al. [70]). Using $\mathrm{LiOH} \mathrm{H}_{2} \mathrm{O}$ as the basic solution gave the first direct evidence of a reaction between $\mathrm{ZnO}$ nanoparticles and unreacted zinc oxy-acetate precursors $\left(\mathrm{Zn}_{4} \mathrm{O}(\mathrm{Ac})_{6}\right)$ to form the $\mathrm{Zn}$-HDS phase (Equation 6) [70].

$$
\mathrm{Zn}_{4} \mathrm{O}(\mathrm{Ac})_{6}+\mathrm{ZnO}+6 \mathrm{H}_{2} \mathrm{O} \rightleftharpoons \mathrm{Zn}_{5}(\mathrm{OH})_{8}(\mathrm{Ac})_{2} \cdot 2 \mathrm{H}_{2} \mathrm{O}+4 \mathrm{HAc}
$$

Two effects are responsible for the formation of Zn-HDS: (1) a slow continuous increase of the $\mathrm{ZnO}$ concentration and a consequent release of $\mathrm{Ac}^{-}$and water, followed by the hydrolytic attack of precursors and a condensation reaction of zinc hydroxyl species; and (2) the occurrence of ethanol esterification, giving rise also to a slow continuous water release [70].

To prevent an increasing $\mathrm{H}_{2} \mathrm{O}$ /ethanol ratio, the formation of secondary phases, like $\mathrm{Zn}-\mathrm{HDS}$, and dissolution of "Zn-O-Zn", we require strong basic conditions, which lead to oxolation reactions, including hydrolysis or condensation forming $\mathrm{Zn}-\mathrm{O}-\mathrm{Zn}$ bridge bonds and precipitation of $\mathrm{ZnO}$ (Scheme 4) [70]. 
Scheme 4. Formation of $\mathrm{Zn}-\mathrm{O}-\mathrm{Zn}$ bridge bonds and precipitation of $\mathrm{ZnO}$ via oxolation reaction.

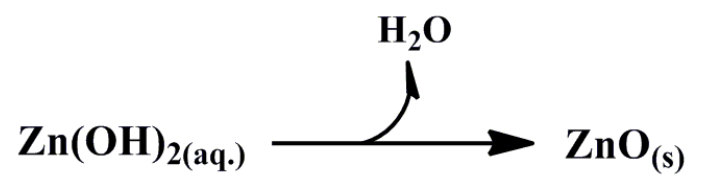

In order to prepare zinc oxide nanostructures with different sizes, shapes and morphologies, the reaction temperature can be also varied. After that, zinc oxide precipitate is separated from the reaction mixture by centrifugation and washed with alcohol or deionized water. The performed TEM measurements by Bahnemann et al. [34] indicate that the reaction mixture contains almost spherical particles with a mean diameter of $50 \AA$ and a relatively narrow size distribution of $( \pm 5 \AA)$. Another approach used by Spanhel et al. [35] with refluxing and by Meulenkamp [37] without refluxing led to $\mathrm{ZnO}$ nanoparticles in a size range from 2 to $7 \mathrm{~nm}$. Pacholski et al. [44] reported the formation of high-quality single crystalline $\mathrm{ZnO}$ nanoparticles in a size range of 3 to $5 \mathrm{~nm}$.

All these results confirm that the choice of the anion, the reaction temperature and time, the nature of the alcohol solvents, as well as storage, humidity and analysis conditions are critical for the preparation of transparent, stable $\mathrm{ZnO}$ colloids via precipitation sol-gel method [52]. It is also well known that colloidal $\mathrm{ZnO}$ nanoparticles (NPs) are not very stable for a long time in solution. Krebs et al. [71] proposed the use of ligands, like amine, thiol or a carboxylic acid, to prevent solid zinc oxide from quick precipitation by a polymerization reaction or aggregation of the particles. From the tested ligands mentioned above, alkoxyacetic acids, like methoxyacetic acid (MA), ethoxyacetic acid (MEA) and methoxyethoxyethoxyacetic acid (MEEA), were found to be the best choice for stabilizing ZnO NPs.

Pure $\mathrm{ZnO}$ thin films deposited from colloidal $\mathrm{ZnO}$ NPs solutions are sensitive to oxidation. Absorption of $\mathrm{O}_{2}$ leads to an undesired decrease of the optical and electrical properties of thin films. In order to overcome this limitation and to make $\mathrm{ZnO}$ films more stable and suitable for (opto)-electronic applications, many research groups prepared doped $\mathrm{ZnO}$ via sol-gel routes $[40,43,66]$. Group III elements, especially $\mathrm{Al}^{3+}$, are good candidates for doping $\mathrm{ZnO}$, because its ionic radius $(0.54 \AA)$ is smaller than that of $\mathrm{Zn}^{2+}$. Therefore $\mathrm{Al}^{3+}$ can occupy the place of $\mathrm{Zn}^{2+}$ in the lattice easily [72]. The precipitation approach described above is not suitable for the preparation of $\mathrm{Al}^{3+}$-doped $\mathrm{ZnO} \mathrm{NPs}$. The reason is that the low-temperature classical sol-gel method used solvents, like $\mathrm{MeOH}\left(65^{\circ} \mathrm{C}\right)$, EtOH $\left(78^{\circ} \mathrm{C}\right)$ or i-PrOH $\left(82^{\circ} \mathrm{C}\right)$, which have low thermal energy and, thus, do not provide enough energy to incorporate dopants into the $\mathrm{ZnO}$ lattice.

\subsubsection{Synthesis of $\mathrm{Al}^{3+}$-Doped $\mathrm{ZnO}$ Based on Precursor Solutions (sAZO)}

One of the most widely reported synthesis routes for $\mathrm{Al}^{3+}$-doped $\mathrm{ZnO}$ (sAZO) are the methods described by Ohyama et al. [40], Alam and Cameron [43]. Synthesis starts in most cases with zinc acetate dihydrate $\left(\mathrm{Zn}(\mathrm{Ac})_{2} \cdot 2 \mathrm{H}_{2} \mathrm{O}\right)$ in various organic solvents, like 2-methoxyethanol, isopropyl alcohol or ethanol. To achieve the desired doping, different $\mathrm{Al}^{3+}$ precursors, like aluminum nitrate $\left(\mathrm{Al}\left(\mathrm{NO}_{3}\right)_{3} \cdot 9 \mathrm{H}_{2} \mathrm{O}\right)$, aluminum acetate $\left(\mathrm{HOAl}\left(\mathrm{C}_{2} \mathrm{H}_{3} \mathrm{O}_{2}\right)_{2}\right)$, aluminum chloride $\left(\mathrm{AlCl}_{3}\right)$ or aluminum chloride hydrate $\left(\mathrm{AlCl}_{3} 6 \mathrm{H}_{2} \mathrm{O}\right)$ are dissolved together with zinc acetate dihydrate and an alcohol in the 
presence of stabilizers, like monoethanolamine (MEA) or diethanolamine (DEA). The resulting solutions are refluxed at $80{ }^{\circ} \mathrm{C}$ for two to $3 \mathrm{~h}$ to obtain clear, stable and transparent precursor solutions. The same procedure can be used also to prepare pure $\mathrm{ZnO}$ precursor solutions without any doping. These precursor solutions can be also directly deposited, but in most cases, a temperature treatment was reported to be essential for the formation of dense $\mathrm{MeO}_{x}$ layers $[23,40,43,66]$.

\subsection{Titanium Dioxide $\left(\mathrm{TiO}_{2}\right)$}

$\mathrm{TiO}_{2}$ is a large band gap semiconductor with three crystalline phases: anatase, rutile and brookite. The most stable phase is rutile, and it is usually obtained after annealing at temperatures above $500{ }^{\circ} \mathrm{C}$. $\mathrm{TiO}_{2}$ is transparent in the visible regime; its band gap is $3.02 \mathrm{eV}$ for rutile, $3.2 \mathrm{eV}$ for anatase and $2.96 \mathrm{eV}$ for brookite [73]. The outermost filled orbitals of elemental titanium (Ti) are $4 \mathrm{~s}^{2}$ and $3 \mathrm{~d}^{2}$, and that of oxygen $(\mathrm{O})$ are $2 \mathrm{~s}^{2}$ and $2 \mathrm{p}^{4}$. In $\mathrm{TiO}_{2}$, the Ti ions are in a distorted octahedral environment and formally have a $\mathrm{Ti}^{4+}\left(3 \mathrm{~d}^{0}\right)$ electronic configuration. The valence band of $\mathrm{TiO}_{2}$ is composed primarily of oxygen $2 \mathrm{p}$ orbital's hybridized with Ti $3 \mathrm{~d}$ states, while the conduction band is purely made up from $3 \mathrm{~d}$ orbital's of titanium [73-75]. Titanium dioxide $\left(\mathrm{TiO}_{2}\right)$ is widely used as an electron extracting material (EEL) or as a transporting material (ETL) in (opto)-electronic applications.

\subsubsection{Synthesis of Colloidal $\mathrm{TiO}_{2}$ Nanoparticles (NPs)}

N. Pinna and M. Niederberger [56,57] report a number of non-hydrolytic sol-gel synthesis methods, where $\mathrm{Ti}(\mathrm{O} i \mathrm{Pr})_{4}, \mathrm{TiCl}_{4}, \mathrm{Ti}(\mathrm{OnBu})_{4}, \mathrm{Ti}(\mathrm{O} t \mathrm{Bu})_{4}$ and different combinations of solvents, like toluene, aldehydes, ketones, ethanol, benzyl alcohol, 1,4-butandiol or $n$-butanol, offer a many-sided reaction system for the preparation of crystalline $\mathrm{TiO}_{2}$ nanoparticles. Most of these reactions take place in an autoclave, and they are known as solvothermal reactions. One of these solvents, benzyl alcohol, has proven its reliability for the synthesis of crystalline metal oxide nanoparticles in the so-called "benzyl alcohol route'. This one pot reaction offers controlled metal oxide formation by using various metal complexes (chlorides, alkoxides, acetates, acetylacetonates) in benzyl alcohol, where the latter is acting as a solvent, ligand and reactant [62].

The use of $\mathrm{TiCl}_{4}$ as a starting precursor is a common choice for the synthesis of colloidal crystalline $\mathrm{TiO}_{2}$ nanoparticles. All reactions can be carried out at temperatures well below the boiling point of the organic solvent in standard laboratory equipment. For the reaction between $\mathrm{TiCl}_{4}$ and benzyl alcohol, two possible reaction mechanisms were outlined by Grote et al. [61]. The first one presents alkyl halide elimination and the second one, ether elimination (Scheme 5) [61].

Scheme 5. Reaction between $\mathrm{TiCl}_{4}$ and benzyl alcohol: (a) alkyl halide elimination; and (b) ether elimination.

(a)

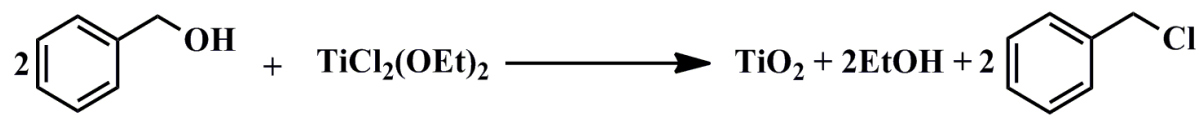

(b)

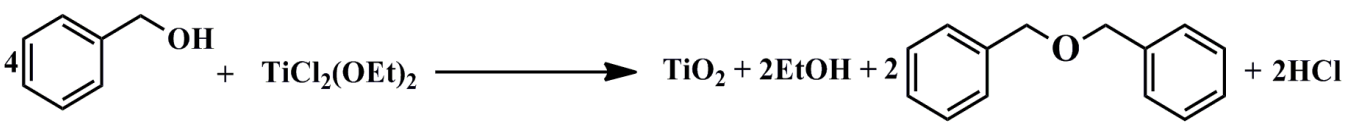


Wang et al. [55] prepared crystalline $\mathrm{TiO}_{2}$ (anatase) nanoparticles using a modified non-hydrolytic sol-gel route reported by Niederberger et al. [56], where titanium tetrachloride $\left(\mathrm{TiCl}_{4}\right)$ and benzyl alcohol provide a versatile reaction system for the synthesis of an anatase nanocrystal sol. An advantage of this non-hydrolytic approach is that there is no need for additional peptizing agents, organic ligands or high temperature treatment [57]. The particle size by this method is $<10 \mathrm{~nm}$ [55].

Jing et al. [74] employed a sol-gel method for the synthesis of $\mathrm{TiO}_{2}$ nanopowder with $\mathrm{Ti}(\mathrm{OBu})_{4}$ as the Ti source. This synthetic route presents a complex approach. First, $\mathrm{Ti}(\mathrm{OBu})_{4}$ was mixed with anhydrous ethanol in a dry atmosphere. Then, the mixed $\mathrm{Ti}(\mathrm{OBu})_{4} /$ ethanol solution was added dropwise into another mixture, which consists of water, anhydrous ethanol and $70 \% \mathrm{HNO}_{3}$, at room temperature, under vigorous stirring, to carry out a hydrolysis. The yellowish transparent sol was produced after continuously stirring for $3 \mathrm{~h}$. After $6 \mathrm{~h}$ at room temperature, the sol was dried at $70{ }^{\circ} \mathrm{C}$ for $2 \mathrm{~h}$, and a gel precursor was obtained. Finally, $\mathrm{TiO}_{2}$ nanopowders were obtained after the thermal treatment of the gel precursor at a certain temperature for $2 \mathrm{~h}$ and a subsequent grinding step [74].

\subsubsection{Synthesis of $\mathrm{TiO}_{2}$ Based on Precursor Solution $\left(\mathrm{sTiO}_{2}\right)$}

In many cases, commercial titanium(IV)-isopropoxide ( $\left.\mathrm{Ti}\left(\mathrm{OCH}\left(\mathrm{CH}_{3}\right)_{2}\right)_{4}\right)$ and titanium(IV)-butoxide $\left(\mathrm{Ti}(\mathrm{O} n \mathrm{Bu})_{4}\right)$ mixed in isopropyl alcohol provide an easy method for the synthesis of the desired $\mathrm{TiO}_{2}$ precursor solutions, which can be used for thin film deposition. After film deposition, these precursor solutions typically require a post treatment to form $\mathrm{TiO}_{x}$. For example, Bolognesi et al. [21], using the method described above, received $\mathrm{TiO}_{x}$ thin films only by drying at $90{ }^{\circ} \mathrm{C}$ for $5 \mathrm{~min}$.

Kim et al. [3] applied a complex synthetic route for the fabrication of $\mathrm{TiO}_{x}$ precursor solution by mixing titanium(IV)-isopropoxide $\left(\mathrm{Ti}\left(\mathrm{OCH}\left(\mathrm{CH}_{3}\right)_{2}\right)\right)$ with 2-methoxyethanol $\left(\mathrm{CH}_{3} \mathrm{OCH}_{2} \mathrm{CH}_{2} \mathrm{OH}\right)$ and ethanolamine $\left(\mathrm{H}_{2} \mathrm{NCH}_{2} \mathrm{CH}_{2} \mathrm{OH}\right)$ in a three-necked flask equipped with a condenser, a thermometer and an argon-gas inlet/outlet. The mixed solution was heated to $80{ }^{\circ} \mathrm{C}$ for $2 \mathrm{~h}$, followed by heating to $120{ }^{\circ} \mathrm{C}$ for $1 \mathrm{~h}$. These two heating steps $\left(80\right.$ and $120^{\circ} \mathrm{C}$ ) were repeated. The final $\mathrm{TiO}_{x}$ precursor solution was prepared in isopropyl alcohol.

Kuwabara et al. [18] prepared $\mathrm{TiO}_{x}$ precursor solutions using the method described by Kim et al. [3]. Ethanolamine (EA), diethanolamine (DEA) and acetyl acetone (AA) were utilized as stabilizers. They found that $\mathrm{EA}^{-\mathrm{TiO}_{x}}$ and $\mathrm{AA}-\mathrm{TiO}_{x}$ precursor solutions took on an orange or yellow color, respectively.

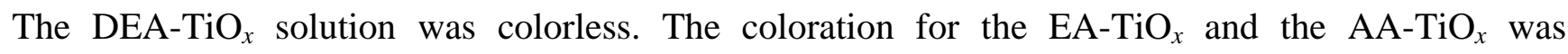
explained as the $\mathrm{d}-\mathrm{d}$ absorption originating from a titanium complex ion formed by the reaction of titanium(IV)-isopropoxide with the stabilizer.

\subsection{Synthesis of p-Type-Like Transition Metal Oxides by Wet Chemical Methods}

Transition $p$-type-like metal oxides $\mathrm{MoO}_{3}, \mathrm{WO}_{3}$ and $\mathrm{V}_{2} \mathrm{O}_{5}$ have various structures and morphologies, which strongly depend on the experimental conditions used. These metals can have different oxidation states, which lead to metal oxides with the same composition and crystal structure, but in general, they exist in various crystal sizes and forms. This is in agreement with the observation that using sol-gel methods to prepare $p$-type-like metal oxides $\mathrm{MoO}_{3}, \mathrm{WO}_{3}$ and $\mathrm{V}_{2} \mathrm{O}_{5}$ allow for the easy variation of the particle morphology. However, synthesis pathways are also much less predictable. In the case of tungsten oxide, the reaction in benzyl alcohol leads to complex lamellar 
tungsten oxide structures with a lateral size length of 30 to $100 \mathrm{~nm}$ [57]. $\mathrm{MoO}_{3}$ has been synthesized in several different morphologies, like large-scale $\alpha-\mathrm{MoO}_{3}$ nanoplatelets [54], aerogels [38,41], xerogels [38,41] and nanoflowers [59]. Similar observations were reported for $\mathrm{V}_{2} \mathrm{O}_{5}$, where the morphologies were nanobelts, nanorolls [50] or nanorods [46]. The metal oxides mentioned above were chemically and physically characterized, but still more efforts and progress are required to better control the synthesis routes and the conversion of the resulting sol-gel solutions into thin films and electrodes. Therefore, we only highlight those wet chemical methods that were already reported for application in inverted BHJ solar cells.

Liu et al. [7] prepared $\mathrm{MoO}_{3}$ precursor solutions via the hydration method using ammonium molybdate $\left(\left(\mathrm{NH}_{4}\right)_{6} \mathrm{Mo}_{7} \mathrm{O}_{24}\right)$ dissolved in water. This solution was mixed with a second solution containing hydrochloric acid $(\mathrm{HCl})$ to get a final $\mathrm{pH}$ value of $1-1.5$. The same procedure could also work in polar organic solvents.

Giroto et al. [8] reported bright yellow $\mathrm{MoO}_{3}$ solutions, which were stable over several days. $\mathrm{MoO}_{3}$ powder was dissolved in $\mathrm{H}_{2} \mathrm{O}_{2}$ and refluxed for $24 \mathrm{~h}$ at $80{ }^{\circ} \mathrm{C}$ in air and cooled to room temperature (RT) for $24 \mathrm{~h}$ to obtain a clear yellow liquid. Furthermore, the viscosity and concentration of the solution was adjusted by the addition of polyethylene glycol and 2-methoxyethanol (volume ratio: 1:0.25:6.25) under refluxing for $30 \mathrm{~min}$ at 70 and $60{ }^{\circ} \mathrm{C}$, respectively. When the $\mathrm{H}_{2} \mathrm{O}_{2}$ amount is not enough for the full conversion of $\mathrm{MoO}_{3}$ into $\mathrm{MoO}_{2}(\mathrm{OH})(\mathrm{OOH})$, they observed that the solution changes its color to dark blue [75].

Zilberberg et al. [13] reported a fast hydrolysis reaction for sol-gel $\mathrm{sMoO}_{x}$ and $\mathrm{sV}_{2} \mathrm{O}_{5}$ based on precursor solution, where precursor molecules (bis(2,4-pentanedionato)-molybdenum (VI)dioxide) and vanadium(V)-oxytriisopropoxide $\left(\mathrm{OV}\left(\mathrm{OCH}\left(\mathrm{CH}_{3}\right)_{2}\right)_{3}\right)$ are dissolved in isopropanol by stirring at room temperature in ambient atmosphere, respectively. Using vanadium(V)-oxytriisopropoxide $\left(\mathrm{OV}\left(\mathrm{OCH}\left(\mathrm{CH}_{3}\right)_{2}\right)_{3}\right)$ dissolved in anhydrous isopropanol (volume ratio: 1:40), Hancox et al. [14] also reported the fabrication of $\mathrm{V}_{2} \mathrm{O}_{x(\text { sol })}$ layers.

Hammond et al. [76] utilized a $\mathrm{sMoO}_{x}$ precursor solution based on metal-organic precursor tricarbonyl trispropionitrile $\left(\mathrm{Mo}(\mathrm{CO})_{3}(\mathrm{EtCN})_{3}\right)$ dissolved in acetonitrile. The mixture was stirred at $60{ }^{\circ} \mathrm{C}$ for $12-20 \mathrm{~h}$ and then filtered.

Choi et al. [11], using the same technique, prepared sol-gel $\mathrm{sWO}_{3}$ based on precursor solution. The starting molecule, tungsten ethoxide $\left(\mathrm{W}_{(}\left(\mathrm{OC}_{2} \mathrm{H}_{5}\right)_{6}\right)$ was dissolved in ethanol at room temperature to give a clear solution.

At the moment, one of the most frequently used methods for the preparation of high grade pure $\mathrm{MoO}_{3}$ or $\mathrm{WO}_{3}$ nanoparticles is the so-called "high-temperature hydrolysis process" or flame spray pyrolysis [63]. After that, the particles are dissolved in the desired organic solvent with or without stabilizing molecules to achieve better dispersion properties.

\section{Requirements for Interface Metal Oxide Materials}

In order to better understand which wet chemical pathways are suitable for the preparation of interface metal oxide materials, we summarize the relevant properties of $n$-type- and $p$-type-like metal oxides for application as a charge injection layer in photovoltaic cells. Ginley et al. [77] already pointed out that the quality of $\mathrm{MeO}_{x}$ films critically impacts the device performance. 
It is well known that $\mathrm{MeO}_{x}$ are wide band gap semiconductors with a relatively high concentration of free electrons in the conduction band. For the present purpose, the $\mathrm{MeO}_{x}$ must carefully balance electrical conductivity and optical transmittance, on the one hand, and stable reproducible chemistry, on the other side. The reduction of the resistivity involves either an increase in the carrier concentration or in the mobility. Increasing the mobility has no negative effect and is most likely the best way to follow [77]. Further, the $\mathrm{MeO}_{x}$ should: (1) favor Ohmic contact formation between electrodes and the active layer; (2) possess suitable energy levels to improve charge selectivity for corresponding electrodes; (3) have a large band gap to confine excitons in the active layer; (4) have sufficient conductivity to reduce resistive losses; (5) have chemical and physical stability to prevent undesirable reactions at the active layer/electrode interface; (6) have the ability to be processed from solution and at low temperatures; (7) be mechanically robust to support multilayer solution processing; (8) have good film forming properties, and, last, but not least, (9) be producible at low cost. At the moment, it is a big challenge to identify metal oxide systems that can simultaneously satisfy all these requirements [78].

The optimization of $\mathrm{MeO}_{x}$ begins with selecting the accurate chemical synthesis methods, which lead to desired products, like nanoparticles or precursor solutions. The classical sol-gel method (precipitation reactions) relies on the formation of metal oxide nanoparticles under strong basic conditions. One disadvantage of this reaction system is the fact that metal oxide particles tend to agglomerate after their dispersion in the desired solvents under the generation of heavy metal hydroxides, like $\mathrm{M}(\mathrm{OH})$ or $\mathrm{M}(\mathrm{OH})_{2}$.

Metal oxide systems from metal alkoxide precursors $\left(\mathrm{M}(\mathrm{OR})_{x-y}\right)$ have the advantage that they are soluble in organic solvents, provide homogenous solutions and can easily be converted by a low temperature treatment into the corresponding metal oxide [65].

The nonaqueous or non-hydrolytic sol-gel processes represent an interesting method to overcome some limitations observed by the classical sol-gel method. The success of these approaches is the versatility of the starting precursors in the reaction mixture and the role of the organic solvents (ethers, alcohols, ketones or aldehydes) as supplying oxygen source for the formation of the metal oxide particles [65].

Oh et al. [23] successful prepared ZnO NPs using the classical sol-gel method (precipitation reaction), $\mathrm{TiO}_{x} \mathrm{NPs}$ applying the nonaqueous sol-gel process and $\mathrm{Al}^{3+}$-doped $\mathrm{ZnO}$ (sAZO) based on the precursor solution. XRD measurements from those three metal oxides as coated films on glass have confirmed their amorphous structure, but after thermal treatment in air, wurtzite (ZnO NPs, sAZO) and anatase $\left(\mathrm{TiO}_{x} \mathrm{NPs}\right)$ structures were found. All films of $\mathrm{ZnO}$ NPs, sAZO and $\mathrm{TiO}_{x} \mathrm{NPs}$ were found to be transparent (over 92\%) in the visible range. Also interesting is the wide range of conductivities reported by the same group. They observed a fairly high conductivity for $\mathrm{TiO}_{x}$ NPs films $\left(4.50 \times 10^{-4} \mathrm{~S} / \mathrm{cm}\right)$ and relatively low conductivity for ZnO NPs films $\left(1.63 \times 10^{-6} \mathrm{~S} / \mathrm{cm}\right)$. In the case of $\mathrm{Al}^{3+}$-doped $\mathrm{ZnO}$ ( $\mathrm{sAZO}$ ), annealing had a strong influence on the conductivity, due to the recrystallization. $\mathrm{Al}^{3+}$-doped $\mathrm{ZnO}(\mathrm{sAZO})$ films annealed at a low temperature $\left(150{ }^{\circ} \mathrm{C}\right)$ had relatively poor conductivity $\left(8.86 \times 10^{-7} \mathrm{~S} / \mathrm{cm}\right)$ compared to sAZO films $\left(2.35 \times 10^{-3} \mathrm{~S} / \mathrm{cm}\right)$ annealed at a high temperature $\left(260^{\circ} \mathrm{C}\right)$. Annealing with even higher temperatures resulted in conductivities above $1 \mathrm{~S} / \mathrm{cm}$.

Stubhan et al. [24] compared the dispersion of ZnO NPs and AZO precursor solution (sAZO). They reported comparable transmittance and device performance for thin $\mathrm{ZnO}$ NPs and sAZO layers. 
Increasing the film thickness $(\sim 126 \mathrm{~nm})$ from ZnO NPs dispersions resulted in a significant performance loss, while cells with comparable sAZO film thickness $(\sim 119 \mathrm{~nm})$ maintained full performance. Comparable device performance for inverted BHJ solar cells based on ZnO NPs and $\mathrm{ZnO}$ precursor solution $(\mathrm{sZnO})$ as the electron transport/extraction layers was reported by Hau et al. [17].

An interesting phenomenon related to the use of $n$-type $\mathrm{MeO}_{x}$ layers is the S-shaped current-voltage $(I-V)$ characteristics, which were reported for $\mathrm{MeO}_{x}$ interface layers from $\mathrm{ZnO}, \mathrm{TiO}_{2}$ or $\mathrm{Al}^{3+}$-doped $\mathrm{ZnO}$. Light soaking under UV radiation is known to release the $S$-shape [79]. The changes in $I-V$ characteristics and the fill factor (FF (\%)) of the inverted solar cells can be correlated with a change in the resistance of the metal oxide thin film. The mechanism behind this is the release of oxygen molecules upon UV irradiation. This results in a decrease in the resistance of the material, due to an increase in the density of mobile charges [79].

Using solution-processed p-type-like transition metal oxides $\mathrm{MoO}_{3}, \mathrm{WO}_{3}$ and $\mathrm{V}_{2} \mathrm{O}_{5}$ as hole extraction/injection layers in inverted BHJ organic solar cells is much more complex. First, they have to be deposited on the top of the photovoltaic active layers, which may cause diverse interactions or chemistry. In addition, post-processing of the sol-gel transition metal oxide layers at high temperatures $\left(300-600{ }^{\circ} \mathrm{C}\right.$ ), which otherwise is required to receive a specific microstructures or crystalline phases, becomes impossible. Such high temperatures are not compatible with the temperature-sensitive polymers and substrates (foils) for the low-cost fabrication of organic solar cells [10].

Despite all the challenges, low temperature solution processed $\mathrm{MoO}_{3}$ and $\mathrm{WO}_{3}$ nanoparticle thin films have been reported $[9,28]$. These particles were prepared by the so-called "high-temperature hydrolysis process" or the flame spray pyrolysis. Furthermore, transition metal oxides based on precursor solutions have been reported, resulting in highly transparent and homogenous solutions $[10,11,13,76]$. However, the electrical, optical and morphological properties (e.g., electrical conductivity, work function (WF), spectral absorption, etc.) of sol-gel processed layers on top of an organic semiconductor are missing [10].

\section{Development of Inverted BHJ Solar Cell}

\subsection{Device Structure}

Today various organic solar cells architectures have been established, such as normal BHJ [3-14], inverted BHJ [15-29] and tandem solar cells [29]. The normal structure (Figure 2a) includes ITO/polyethylene dioxythiophene:polystyrene sulfonate (PEDOT:PSS)/photoactive layer/low work function(LWF) metal from bottom to top. LWF metal as the cathode is a primary limit to the interface stability of devices, since metals $(\mathrm{Li}, \mathrm{Ca}$, and $\mathrm{Al}$ ) are prone to be oxidized, resulting in the increase of series resistance at the organic/electrode interfaces. In addition, oxygen preferably diffuses into the photoactive layer through pinholes and grain boundaries through the cathode, degrading the active layer and making the device instable in air. On the other hand, the ITO/PEDOT:PSS interface is also instable, due to likely indium diffusion into the photoactive layer and the ITO etching by acidic PEDOT:PSS adsorbing water. The reaction between PSS and water induces a faster degradation of the ITO/PEDOT:PSS interface [2]. 
Figure 2. (a) Schematic device structure of the conventional polymer solar cell; and (b) schematic device structure of the inverted polymer solar cell. SC (Semiconductor); BHJ (inverted bulk heterojunction); PEDOT:PSS (polyethylene dioxythiophene:polystyrene sulfonate); ITO (indium tin oxide); WF (work function).

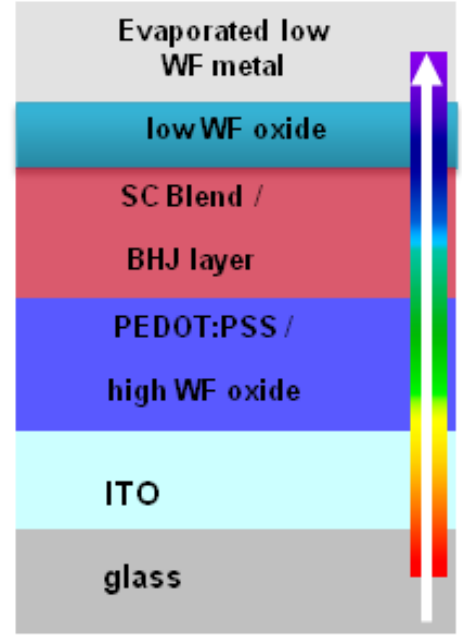

(a)

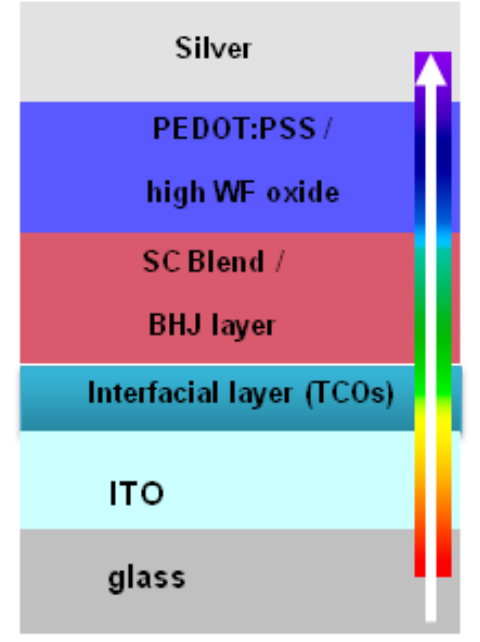

(b)

To overcome the instability issue in the normal structure device, one feasible approach is to construct an inverted configuration [2,30], where ITO serves as the cathode, as shown in Figure 2b.

It should be pointed out that only modified ITO can serve as the cathode for electron extraction. The functional layers for modifying ITO mainly focus on metal oxides, such as $\mathrm{ZnO}, \mathrm{Al}^{3+}$-doped $\mathrm{ZnO}$, $\mathrm{TiO}_{2}$ and alkali-metal compounds, like $\mathrm{Cs}_{2} \mathrm{CO}_{3}[2]$.

\section{2. $\mathrm{ZnO}, \mathrm{Al}^{3+}$-Doped $\mathrm{ZnO}$ and $\mathrm{TiO}_{2}$ as the Cathode Interlayer in an Inverted Solar Cell}

Due to their chemical resistance to oxygen and moisture, optical transparency and facile solution processability, these $n$-type semiconducting oxides effectively replace low work function metals for cathode contacts, resulting in high efficiency devices.

White et al. [16] successful applied $\mathrm{ZnO}$ based on precursor solution via spin coating as the blocking hole interlayer between the ITO and the active layer (P3HT: PCBM 1:1) using Ag as the hole-collecting back contact. Their inverted architecture with modified ITO shows high external quantum efficiency (EQE), suggesting that the electron mobility of the solution-cast $\mathrm{ZnO}$ layer is large enough for fast electron transfer from PCBM to $\mathrm{ZnO}$, with no buildup of electrons at the $\mathrm{ZnO}$ /organic interface occurring. They also found that electron transfer from PCBM to ZnO does not result in a significant loss in energy, indicating that the LUMO of PCBM is close to the conduction band energy of $\mathrm{ZnO}$ at $-4.1 \mathrm{eV}$.

Hau et al. [17] were able to improve the short-circuit current density $\left(J_{\mathrm{SC}}\right)$ and open-circuit voltage $\left(V_{\mathrm{OC}}\right)$ of inverted polymer solar cells compared to their conventional architecture pendants, by using $\mathrm{ZnO}$ based on a colloidal suspension, as well as precursor solutions on both ITO-coated glass substrates and ITO-coated plastic substrates. The devices with ZnO NPs and ZnO precursor solution on ITO-coated glass showed very similar characteristics, with a power conversion efficiency (PCE) of $\sim 3.6 \%$. For the devices produced on ITO-coated plastic, they observed a lower PCE of $\sim 3.3 \%$ 
compared to ITO-coated glass samples, reflecting the lower transparency of the flexible ITO substrates.

Park et al. [20] used $\mathrm{ZnO}$ as an electron transport buffer layer based on precursor solution deposited via spin coating. After deposition of the $\mathrm{ZnO}$ thin films one, two, three, and four times, they observed formation of wrinkles and a little curvature on the metal oxide surface. The device characteristic confirmed that solar cell parameters, like open circuit voltage $\left(V_{\mathrm{OC}}\right)$, short circuit current $\left(J_{\mathrm{SC}}\right)$ and fill factor (FF), were influenced by the $\mathrm{ZnO}$ film thickness and transparency. They claimed the formation of more percolation pathways of the $\mathrm{ZnO}$ buffer layer by increasing the thickness.

Oh et al. [23], using a $\mathrm{ZnO}$ nanoparticles suspension, also found that the performance of the inverted solar cell is strongly dependent on the thickness of the $\mathrm{ZnO}$ buffer layer.

Still, there are many problems associated with substituting ZnO-based electron extraction layers. According to Lee et al. [27], low-temperature synthesized $\mathrm{ZnO}$ thin films have low quality and low optical properties, due to the unexpected defects. In some cases, devices based on colloidal ZnO NPs require UV light treatment to improve their conductivity. This effect was tested by Lee et al. [27] in the device structure of ITO/ZnO/P3HT:PCBM/ $\mathrm{MoO}_{3} / \mathrm{Au}$, and the experimental results showed that the transmittance of the $\mathrm{ZnO}$ thin layer increased after UV light illumination, followed by an increase in the open circuit current $\left(J_{\mathrm{SC}}\right)$, while the values for the open circuit voltage $\left(V_{\mathrm{OC}}\right)$ remained almost constant [27]. However, according to Chen et al. [30], this photo-doping effect only lasts for a short time. In order to enhance the stability of colloidal ZnO NPs solutions, Krebs et al. [71] proposed the use of ligands to prevent aggregation and to stabilize the zinc oxide nanoparticles.

One of the most used chemical approaches to enhance device performance is to effectively dope $\mathrm{ZnO}$ with trivalent elements from the group III ( $\mathrm{Al}, \mathrm{Ga}, \mathrm{In})$. The ionic radius of $\mathrm{Al}^{3+}$ is $0.54 \AA$ and is smaller than that of $\mathrm{Zn}^{2+}(0.74 \AA)$, allowing $\mathrm{Al}^{3+}$ to substitute $\mathrm{Zn}^{2+}$ in the lattice. The resistivity of the $\mathrm{AZO}$ film decreased with an increase of the $\mathrm{Al}$ content up to a few atomic percentages (at\%). At a high $\mathrm{Al}^{3+}$ concentration, $\mathrm{Al}^{3+}$ exists in the form of $\mathrm{Al}_{2} \mathrm{O}_{3}$, resulting in the deterioration of electrical properties [72].

Sol-gel based methods have been established for the fabrication of inverted solar cells based on $\mathrm{Al}^{3+}$-doped $\mathrm{ZnO}$. Oh et al. [23] fabricated efficient solar cells organic solar cells with an inverted device geometry, where sAZO precursor solution with different $\mathrm{Al}^{3+}$ content $(0.5,1$ and 2 at \%) was coated onto ITO-glass substrates as a bottom electrode interlayer. They concluded that the variation of the doping degree between $0.5 \%$ and $2 \%$ did not make a major impact on the device performance. The resulting device performance was influenced by the annealing temperature, and the obtained PCEs were between $2.18 \%$ and $2.59 \%$.

Stubhan et al. [24] compared a dispersion of i-ZnO nanoparticles (ZnO NPs) and a sAZO precursor solution, as electron injection layers. Increasing the film thicknesses of both materials showed that the performance of the sAZO inverted solar cell did not change with increasing film thickness compared to $\mathrm{i}-\mathrm{ZnO}$ nanoparticle thin films. The conductivity of sAZO thin films was reported to be one to two orders of magnitude higher than that for $\mathrm{i}-\mathrm{ZnO}$ films.

$\mathrm{TiO}_{2}$ as the electron collection electrode in inverted BHJ solar cells was reported by Waldauf et al. [15]. They prepared inverted devices (ITO/TiO $/$ RR-P3HT:PCBM/PEDOT:PSS/Au) via coating techniques and demonstrated improved fill factors (FF, 62\%) for the inverted architecture compared to the conventional architecture with an FF of 59\%. Kuwabara et al. [18] reported efficient 
inverted BHJ solar cells by comparing different types of $\mathrm{TiO}_{x}$ precursor solutions. They observed an improved short-circuit photocurrent $\left(J_{\mathrm{SC}}\right)$, open-circuit voltage $\left(V_{\mathrm{OC}}\right)$, fill factor $(\mathrm{FF} \%)$ and the power conversion efficiency $(\eta)$. Oh et al. [23] also reported an efficient inverted BHJ solar cell based on optimized $\mathrm{TiO}_{x} \mathrm{NP}$ solution as the electron extraction layer.

Thin transparent electrodes based on $\mathrm{TiO}_{2}$ solutions were also propagated as an optical spacer for improving light absorption in the active film. For thin active layers, Kim et al. [3] and Roy et al. [5] reported higher short current densities, due to an improved light management with a $\mathrm{TiO}_{2}$ electron extracting layer.

The importance of the interface materials is demonstrated even more powerfully for the third generation of polymeric semiconductors, like poly[N-9"-hepta-decanyl-2,7-carbazole-alt-5,5-(4',7'-di2-thienyl-2',1',3'-benzothiadiazole)] (PCDTBT), dithienosilole-thienopyrrole-4,6-dione (PDTS-TPD) or dithienogermole-thienopyrrole-4,6-dione, which are more air-stable photoactive materials compared to the poly(3-hexylthiophene) (P3HT) high-efficiency solar cells that are fabricated. For example, Sun et al. [25] demonstrated an efficient inverted BHJ solar cell based on sol-gel-derived $\mathrm{ZnO}$ as a bottom cathode and reported efficiencies of up to $6.08 \%$.

The performance parameters $\left(V_{\mathrm{OC}}(\mathrm{V}) ; J_{\mathrm{SC}}\left(\mathrm{mA} / \mathrm{cm}^{2}\right)\right.$; FF $(\%)$; PCE $(\%)$ ) of $\mathrm{ZnO}, \mathrm{Al}^{3+}$-doped $\mathrm{ZnO}$ and $\mathrm{TiO}_{2}$ used as the cathode interlayers in inverted organic BHJ solar cells are tabulated in the following Table 1 .

Table 1. Device parameters of i-BHJ solar cells with different electron transport/extraction interlayers. EEL, electron extraction layer; ETL, electron transport layer; $V_{\mathrm{OC}}$, open-circuit voltage; $J_{\mathrm{SC}}$, short-circuit current density; FF, fill factor; NP, nanoparticle.

\begin{tabular}{|c|c|c|c|c|c|}
\hline Reference $\left(\mathbf{N}^{\circ}\right)$ & EEL/ETL & $V_{\mathrm{OC}}(\mathrm{V})$ & $J_{\mathrm{SC}}\left(\mathrm{mA} / \mathrm{cm}^{2}\right)$ & FF\% & PCE\% \\
\hline [17] (P3HT:PCBM) & $\mathrm{ZnO} \mathrm{NP}$ & 0.62 & 11.17 & 54.3 & 3.78 \\
\hline [23] (P3HT:PCBM) & $\mathrm{ZnO} \mathrm{NP}$ & 0.56 & 8.33 & 56.5 & 2.62 \\
\hline [24] (P3HT:PCBM) & $\mathrm{ZnO} \mathrm{NP}$ & 0.56 & 8.36 & 53.9 & 2.56 \\
\hline [16] (P3HT:PCBM) & $\mathrm{s}(\mathrm{ZnO})$ & 0.55 & 9.23 & 51.8 & 2.65 \\
\hline [20] (P3HT:PCBM) & $\mathrm{s}(\mathrm{ZnO})$ & 0.55 & 8.86 & 45.5 & 2.21 \\
\hline [23] (P3HT:PCBM) & $\mathrm{s}(\mathrm{AZO})$ & 0.57 & 9.57 & 47.7 & 2.59 \\
\hline [24] (P3HT:PCBM) & $\mathrm{s}(\mathrm{AZO})$ & 0.57 & 8.36 & 50.8 & 2.42 \\
\hline [23] (P3HT:PCBM) & $\mathrm{TiO}_{2} \cdot \mathrm{NP}$ & 0.57 & 8.38 & 54.4 & 2.58 \\
\hline [18] (P3HT:PCBM) & $\mathrm{s}\left(\mathrm{EA}-\mathrm{TiO}_{x}\right)$ & 0.56 & 6.70 & 55.0 & 2.06 \\
\hline [18] (P3HT:PCBM) & $\mathrm{s}\left(\mathrm{DEA}^{\left.-\mathrm{TiO}_{x}\right)}\right.$ & 0.55 & 5.31 & 36.0 & 1.06 \\
\hline [18] (P3HT:PCBM) & $\mathrm{s}\left(\mathrm{AA}-\mathrm{TiO}_{x}\right)$ & 0.55 & 7.00 & 60.0 & 2.31 \\
\hline [21] (P3HT:PCBM) & $\mathrm{sTiO}_{2}$ & 0.55 & 9.06 & 51.9 & 2.61 \\
\hline
\end{tabular}

\section{3. $\mathrm{MoO}_{3}, \mathrm{WO}_{3}$ and $\mathrm{V}_{2} \mathrm{O}_{5}$ as the Anode Interlayer in an Inverted Solar Cell}

The binary $\mathrm{MeO}_{x}$, such as $\mathrm{MoO}_{3}, \mathrm{WO}_{3}$ and $\mathrm{V}_{2} \mathrm{O}_{5}$, are $n$-type oxides. Due to their low lying conduction band, these $\mathrm{MeO}_{x}$ were reported to $p$-dope most organic semiconductors, which makes them suitable as hole extraction layers. Here, we will focus on solution processed $\mathrm{MoO}_{3}, \mathrm{WO}_{3}$ and $\mathrm{V}_{2} \mathrm{O}_{5}$ thin films as hole extraction/injection layers in inverted BHJ solar cells. At the moment, the most widely used hole injection/extraction layers (HIL/HEL) in organic photovoltaic are based on polyethylene dioxythiophene:polystyrene sulfonate (PEDOT:PSS). According to Meyer et al. [31], the 
aqueous PEDOT:PSS solution and its acidic nature can cause the degradation of subsequently deposited organic films or electrode materials. In addition, PEDOT:PSS has a relatively low WF of $5.0 \mathrm{eV}$, which can limit charge extraction from deep HOMO polymers. In comparison, experimental PES/IPES measurement, outlined also by Meyer et al. [31,80], showed that $\mathrm{V}_{2} \mathrm{O}_{5}$ has the largest WF $(7.0 \mathrm{eV})$, closely followed by $\mathrm{MoO}_{3}$ and $\mathrm{WO}_{3}$ with $\mathrm{WF}$ values of $6.9 \mathrm{eV}$ and $6.7 \mathrm{eV}$, respectively. Another interesting point is the fact that $\mathrm{MeO}_{x}$, like $\mathrm{MoO}_{3}, \mathrm{WO}_{3}$ and $\mathrm{V}_{2} \mathrm{O}_{5}$, do not act as the electron blocking layer, because their conduction band (CB) edge is too low $[31,80,81]$.

However, access to solution-based $p$-type-like metal oxides open the way to replacing PEDOT:PSS as the hole-injection or hole-extraction layer and to improving the performance of the organic solar cells.

Zilberberg et al. [26] reported an inverted BHJ solar cells ( $\mathrm{TCO} / \mathrm{TiO}_{x} / \mathrm{P} 3 \mathrm{HT}: \mathrm{PCBM} / \mathrm{sV}_{2} \mathrm{O}_{5} / \mathrm{Ag}$ ) based on $\mathrm{sV}_{2} \mathrm{O}_{5}$ spin-coated precursor films as hole-extraction layers. They found that the thickness of $\mathrm{sV}_{2} \mathrm{O}_{5}$ thin film critically influences solar cell performance. Comparable $V_{\mathrm{OC}}$ values for an inverted solar cell with a solution-processed $\mathrm{sV}_{2} \mathrm{O}_{5}$ layer and with an evaporated $\mathrm{eV}_{2} \mathrm{O}_{5}$ layer were observed. Using the same preparation method for $\mathrm{sVO}_{x}$ precursor solution (VTIPO (vanadium (V) triisopropoxy oxide)), Chen et al. [22] fabricated an inverted BHJ solar cell with the layered configuration of glass/ITO/ZnO/polymer (P3HT or a-PTPTBT):PCBM/ $/ \mathrm{SV}_{2} \mathrm{O}_{5}$ or $\mathrm{VO}_{x} / \mathrm{Ag}$, where $\mathrm{V}_{2} \mathrm{O}_{5}$ powder was homogenously dispersed and suspended in isopropyl alcohol (IPA). They suggested that $\mathrm{VO}_{x}$ layers based on precursor solutions provided improved device characteristic for both organic polymers used (P3HT or poly(thiophene-phenylene-thiophene)-(2,1,3-benzothiadiazole) (a-PTPTBT)) compared to solar cells with $\mathrm{sV}_{2} \mathrm{O}_{5}$ and PEDOT:PSS.

Sun et al. [25] combined both cathode and anode interface layer $\mathrm{ZnO}$ and evaporated $\mathrm{MoO}_{3}$ to prepare efficient inverted BHJ solar cell based on PCDTBT:PC ${ }_{70} \mathrm{BM}$. Their investigations focused on the annealing temperatures of $\mathrm{ZnO}$ and concluded that $150{ }^{\circ} \mathrm{C}$ or $200{ }^{\circ} \mathrm{C}$ annealed layers show higher performance (PCE $\sim 6 \%$ ) than layers annealed at $130{ }^{\circ} \mathrm{C}$. Solution-processed $\mathrm{sMoO}_{3}$ as a PEDOT:PSS replacement was reported by Stubhan et al. [9] for a normal architecture device (Glass/ITO/sMoO 3 /P3HT:PCBM/Al). They observed that the solar cell performance and, here, especially, the short circuit current $\left(J_{\mathrm{SC}}\right)$ were critically influenced by three effects, depending on the $\mathrm{sMoO}_{3}$ layer thickness (optical losses, serial resistance $\left(\mathrm{R}_{\mathrm{S}}\right)$ and surface roughness). Tungsten oxide $\left(\mathrm{WO}_{3}\right)$ formed by sol-gel chemistry was also successful applied as PEDOT:PSS replacement in a conventional device by Choi et al. [11].

Ning et al. [28,29] and Stubhan et al. [12] finally demonstrated that $\mathrm{sWO}_{3}$ based on nanoparticle solutions does show full device performance in inverted organic photovoltaic (OPV) devices (ITO/Al-ZnO/P3HT or Si-PCPDTBT/sWO 3 NP/Ag). The same conclusion as previously drawn by Stubhan et al. [9] for $\mathrm{sMoO}_{3}$, namely, the critical importance of film quality was also reported in this work.

The performance parameters: $V_{\mathrm{OC}}(\mathrm{V}) ; J_{\mathrm{SC}}\left(\mathrm{mA} / \mathrm{cm}^{2}\right)$; FF $(\%)$; PCE $(\%)$ of $\mathrm{MoO}_{3}, \mathrm{WO}_{3}$ and $\mathrm{V}_{2} \mathrm{O}_{5}$ used as anode interlayers in inverted or conventional organic BHJ solar cells are summarized in the following Table 2 . 
Table 2. Device parameters of i-BHJ solar cells with different hole transport/extraction interlayers. HEL, hole extraction layer; HTL, hole transport layer.

\begin{tabular}{|c|c|c|c|c|c|}
\hline Reference $\left(\mathbf{N}^{\circ}\right)$ & HEL/HTL & $V_{\text {OC }}(\mathrm{V})$ & $J_{\mathrm{SC}}\left(\mathrm{mA} / \mathrm{cm}^{2}\right)$ & FF\% & РCE\% \\
\hline [26] (P3HT:PCBM) & $\mathrm{V}_{2} \mathrm{O}_{5} \mathrm{NP}$ & 0.56 & 10.4 & 66.0 & 3.80 \\
\hline [26] (P3HT:PCBM) & $\mathrm{sV}_{2} \mathrm{O}_{5}$ & 0.52 & 9.50 & 60.0 & 3.00 \\
\hline [22] (P3HT:PCBM) & $\mathrm{sVO}_{x}$ & 0.57 & 10.1 & 67.0 & 3.90 \\
\hline [20] (P3HT:PCBM) & $\mathrm{eMoO}_{3}$ & 0.55 & 8.86 & 45.5 & 2.21 \\
\hline [25] (PCDTBT:PC $\left.{ }_{70} \mathrm{BM}\right)$ & $\mathrm{eMoO}_{3}$ & 0.88 & 10.4 & 68.8 & 6.08 \\
\hline [9] con. (P3HT:PCBM) & $\mathrm{sMoO}_{3}$ & 0.57 & 7.96 & 66.7 & 2.92 \\
\hline [11] con. (P3HT:PCBM) & $\mathrm{sWO}_{3}$ & 0.62 & 8.63 & 63.0 & 3.37 \\
\hline [28] (P3HT/PCDTBT:PCBM) & $\mathrm{sWO}_{3}$ & 0.53 & 8.56 & 52.6 & 2.68 \\
\hline [12] (P3HT/PCDTBT:PCBM) & $\mathrm{sWO}_{3}$ & 0.54 & 8.50 & 51.3 & 2.40 \\
\hline
\end{tabular}

\section{Device Stability}

The development of stable and efficient inverted BHJ solar cells requires intensive device stability testing. Most studies, however, focus on the fundamental degradation mechanisms of the organic semiconductors, rather than the interfaces $[10,17,82]$. It is well known that oxygen and moisture lead to the degradation of the polymers and polymer/oxide composites. The inverted solar cell architecture clearly bears the advantage of separating the acidic poly (3,4-ethylenedioxythiophene):poly(styrenesulfonate) (PEDOT:PSS) from the indium tin oxide (ITO) electrode and of replacing non-noble metal cathodes. The additional positive impact of $\mathrm{MeO}_{x}$ on the lifetime of organic solar cells is currently under discussion.

Kuwabara et al. [18] performed durability tests on ITO/TiO $/$ /PCBM:P3HT/PEDOT:PSS/Au inverted-type BHJ organic solar cells in an ambient atmosphere. They observed that the solar cells with amorphous $\mathrm{TiO}_{x}$ had high durability under continuous irradiation for $120 \mathrm{~h}$ in air (efficiency decrease by approximately $70 \%$ ), while sealed devices maintained efficiency under continuous light irradiation for $120 \mathrm{~h}$.

Hau et al. [17] explored the stability of ITO/ZnO NPs/P3HT:PCBM/PEDOT:PSS/Ag solar cells, where the samples were stored in air under ambient conditions for 40 days. For the conventional devices based on LiF/Al electrodes, they observed drastic degradation after one day of storage, and after four days, the cells were completely degraded. In contrast, inverted-type cells showed relatively constant $\mathrm{FF}$ and $V_{\mathrm{OC}}$ values over the period of 40 days, with only slight $J_{\mathrm{SC}}$ reduction. The improved lifetime was correlated to the use of an air-stable Ag top electrode.

White et al. [16] tested device durability by measuring the performance of an inverted solar cell (ITO/sZNO/P3HT:PCBM/Ag) after different periodic exposures to air. Four days after fabrication, the device efficiency dropped to $\eta=2.58 \%$ from $\eta=2.97 \%$, and after seven days, the efficiency was $\eta=2.32 \%$. They realized that the whole device performance improved upon exposure of the $\mathrm{ZnO}$ and Ag surface to air, but the P3HT:PCBM layer was responsible for the observed degradation under ambient atmosphere.

Hauch et al. [82] applied the accelerated lifetime (ALT) test with conditions close to international standards for inorganic solar cells. Further, using this degradation test, they investigated the degradation of flexible encapsulated P3HT:PCBM cells by three different climate conditions: $65{ }^{\circ} \mathrm{C}$ 
(high $\mathrm{T}$ dark storage), $65^{\circ} \mathrm{C} / 1$ sun (sun soak) and $65{ }^{\circ} \mathrm{C} / 85 \%$ relative humidity (rh) (damp heat). They determined that different environmental stress conditions led to different types of degradation behavior, which also differently influenced the solar cell parameters, like $V_{\mathrm{OC}}, J_{\mathrm{SC}}, \mathrm{FF}$ and efficiency (ๆ) [82]. With this experimental data, they were able to show that P3HT:PCBM cells are considerably less sensitive to water and oxygen, as expected.

Sun et al. [25] exposed the following inverted cell architecture, ITO/sZnO/PCDTBT:PC $70 \mathrm{BM} / \mathrm{MoO}_{x} / \mathrm{Ag}$, continuously to air at room temperature without encapsulation for 30 days. The cells with $\mathrm{MoO}_{x}$ as the hole transport layer showed PCEs of $70 \%$ of its original value after 30 days.

\section{Summary and Outlook}

In the past couple of years, numerous wet chemical synthesis methods for nanoscale metal oxides have been described. Such synthesis routes provide access to nanoparticles with different chemical compositions, monodisperse crystallite sizes, demanding crystal forms and complex configurations. There is no doubt that the physical and chemical properties of the synthesized metal oxide nanoparticles, compared to synthesis pathways, require further detailed work and investigation. From this point of view, in-depth studies of synthesis and product characteristics are an important step on the way to implementing faster, new technological applications.

The non-aqueous sol-gel methods, compared to classical sol-gel methods, offer the possibility for stable synthesis methods for metal oxide nanoparticles. Due to their simplicity and robustness, the reaction conditions exhibit only slight deviations, which typically do not impact the morphological properties of the nanoparticles.

Despite all the efforts and the enormous progress in the field of nanoparticle research, the prime goal is and remains the development of new synthesis strategies for metal oxide particles, allowing one to precisely predict the composition, structure, size, form and opto-electronic properties.

Metal oxide semiconductor nanocrystals based on sol-gel synthesis routes, like $\mathrm{ZnO}$, $\mathrm{Al}^{3+}$-doped $\mathrm{ZnO}, \mathrm{TiO}_{2}, \mathrm{~s}-\mathrm{WO}_{3}, \mathrm{~s}-\mathrm{MoO}_{3}$ and $\mathrm{s}-\mathrm{V}_{2} \mathrm{O}_{5}$, have attracted intensive interest during the last 10 years, because their outstanding optical and electrical properties qualify them for multiple opto-electronic applications, like flat screens, touch screens, sensors, photodetectors or thin film solar cells. To realize such large-scale production of these layers, we require cost-effective synthesis methods, which provide high quality layers.

Research in the field of the solution-processed organic polymer solar cells has already demonstrated that using $\mathrm{i}-\mathrm{ZnO}, \mathrm{Al}^{3+}$-doped $\mathrm{ZnO}$ or $\mathrm{TiO}_{2}$ as electron transport/extraction interfaces and $\mathrm{WO}_{3}, \mathrm{MoO}_{3}$ or $\mathrm{V}_{2} \mathrm{O}_{5}$ as hole transport/extraction interlayers are viable strategies. Efficient solar cells with superior environmental stability were reported with $\mathrm{MeO}_{x}$ interface layers. Tables 1 and 2 in Section 5 summarize, once again, the performance parameters $\left(V_{\mathrm{OC}}(\mathrm{V}) ; J_{\mathrm{SC}}\left(\mathrm{mA} / \mathrm{cm}^{2}\right)\right.$; FF $(\%)$; PCE $\left.(\%)\right)$ for various inverted organic BHJ solar cells.

Interestingly, many different synthesis routes for the various $\mathrm{MeO}_{x}$ yielded more or less identical device functionality and performance. Despite the efforts of the last few years, there is still insufficient understanding of how to correlate the detailed chemical and physical properties of thin sol-gel $\mathrm{MeO}_{x}$ to solar cell performance. Light soaking, current mismatching or the observed degradation trends underline that the precise function of $\mathrm{MeO}_{x}$ layers and their impact on the degradation mechanism is 
not understood. More fundamental investigation on the pristine layers is required to further enhance the intrinsic stability of $\mathrm{MeO}_{x}$ thin films and to pave the way for the fabrication of more efficient and stable organic BHJ solar cells.

\section{Acknowledgments}

The authors gratefully acknowledge the Cluster of Excellence "Engineering of Advanced Materials" at the University of Erlangen-Nuremberg, which is funded by the German Research Foundation (DFG), the Solar goes Hybrid project and Energy Campus Nuremberg (EnCN) for the financial support.

\section{Conflicts of Interest}

The authors declare no conflict of interest.

\section{References}

1. Li, J.; Yu, H.-Y. Enhancement of Si-Based Solar Cell Efficiency via Nanostructure Integration. In Energy Eficiency and Renewable Energy through Nanotechnology; Zang, L., Ed; Springer-Verlag: London, UK, 2011; Volume 2011, pp. 3-55.

2. Fung, D.D.S..; Choy, W.C.H. Introduction to Organic Solar Cells. Organic Solar Cells: Materials and Device Physics; Choy, W.C.H., Ed.; Springer-Verlag: London, UK, 2013; Volume 2013, pp. 1-16.

3. Kim, J.Y.; Kim, S.H.; Lee, H.H.; Lee, K.; Ma, W.; Gong, X.; Heeger, A.J. New architecture for high-efficiency polymer photovoltaic cells using solution-based titanium oxide as an optical spacer. Adv. Mater. 2006, 18, 572-576.

4. Dennler, G.; Scharber, M.C.; Brabec, C.J. Polymer-fullerene bulk-heterojunction solar cells. Adv. Mater. 2009, 21, 1323-1338.

5. Roy, A.; Park, S.H.; Cowan, S.; Tong, M.H.; Cho, S.; Lee, K.; Heeger, A.J. Titanium suboxide as an optical spacer in polymer solar cells. Appl. Phys. Lett. 2009, 95, 013302:1-013302:3.

6. Brabec, C.J.; Gowrisanker, S.; Halls, J.J.; Laird, D.; Jia, S.; Williams, S.P. Polymer-fullerene bulk-heterojunction solar cells. Adv. Mater. 2010, 22, 3839-3856.

7. Liu, F.; Shao, S.; Guo, X.; Zhao, Y.; Xie, Z. Efficient polymer photovoltaic cells using solution-processed $\mathrm{MoO}_{3}$ as anode buffer layer. Sol. Energy Mater. Sol. Cells 2010, 94, 842-845.

8. Girotto, C.; Voroshazi, E.; Cheyns, D.; Heremans, P.; Rand, B.P. Solution-processed $\mathrm{MoO}_{3}$ thin films as a hole-injection layer for organic solar cells. ACS Appl. Mater. Interfaces 2011, 3, 3244-3247.

9. Stubhan, T.; Ameri, T.; Salinas, M.; Krantz, J.; Machui, F.; Halik, M.; Brabec, C.J. High shunt resistance in polymer solar cells comprising a $\mathrm{MoO}_{3}$ hole extraction layer processed from nanoparticle suspension. Appl. Phys. Lett. 2011, 98, 253308:1-253308:3.

10. Zilberberg, K.; Trost, S.; Schmidt, H.; Riedl, T. Solution processed vanadium pentoxide as charge extraction layer for organic solar cells. Adv. Energy Mater. 2011, 1, 377-381. 
11. Choi, H.; Kim, B.; Ko, M.J.; Lee, D.-K.; Kim, H.; Kim, S.H.; Kim, K. Solution processed $\mathrm{WO}_{3}$ layer for the replacement of PEDOT:PSS layer in organic photovoltaic cells. Org. Electron. 2012, 13, 959-968.

12. Stubhan, T.; Li, N.; Luechinger, N.A.; Halim, S.C.; Matt, G.J.; Brabec, C.J. High fill factor polymer solar cells incorporating a low temperature solution processed $\mathrm{WO}_{3}$ hole extraction layer. Adv. Energy Mater. 2012, 2, 1433-1438.

13. Zilberberg, K.; Gharbi, H.; Behrendt, A.; Trost, S.; Riedl, T. Low-temperature, solution-processed $\mathrm{MoO}_{x}$ for efficient and stable organic solar cells. ACS Appl. Mater. Interfaces 2012, 4, 1164-1168.

14. Hancox, I.; Rochford, L.A.; Clare, D.; Walker, M.; Mudd, J.J.; Sullivan, P.; Schumann, S.; McConville, C.F.; Jones, T.S. Optimization of a high work function solution processed vanadium oxide hole-extracting layer for small molecule and polymer organic photovoltaic cells. J. Phys. Chem. C 2013, 117, 49-57.

15. Waldauf, C.; Morana, M.; Denk, P.; Schilinsky, P.; Coakley, K.; Choulis, S.A.; Brabec, C.J. Highly efficient inverted organic photovoltaics using solution based titanium oxide as electron selective contact. Appl. Phys. Lett. 2006, 89, 233517:1-233517:3.

16. White, M.S.; Olson, D.C.; Shaheen, S.E.; Kopidakis, N.; Ginley, D.S. Inverted bulk-heterojunction organic photovoltaic device using a solution-derived $\mathrm{ZnO}$ underlayer. Appl. Phys. Lett. 2006, 89, 143517:1-143517:3.

17. Hau, S.K.; Yip, H.-L.; Baek, N.S.; Zou, J.; O’Malley, K.; Jen, A.K.Y. Air-stable inverted flexible polymer solar cells using zinc oxide nanoparticles as an electron selective layer. Appl. Phys. Lett. 2008, 92, 253301:1-253301:3.

18. Kuwabara, T.; Nakayama, T.; Uozumi, K.; Yamaguchi, T.; Takahashi, K. Highly durable inverted-type organic solar cell using amorphous titanium oxide as electron collection electrode inserted between ITO and organic layer. Sol. Energy Mater. Sol. Cells 2008, 92, 1476-1482.

19. Tao, C.; Ruan, S.; Xie, G.; Kong, X.; Shen, L.; Meng, F.; Liu, C.; Zhang, X.; Dong, W.; Chen, W. Role of tungsten oxide in inverted polymer solar cells. Appl. Phys. Lett. 2009, 94, 043311:1-043311:3.

20. Park, H.-J.; Lee, K.-H.; Kumar, B.; Shin, K.-S.; Jeong, S.-W.; Kim, S.-W. Inverted organic solar cells with $\mathrm{ZnO}$ thin films prepared by sol-gel method. J. Nanoelectron. Optoelectron. 2010, 5, 135-138.

21. Bolognesi, M.; Sanchez-Diaz, A.; Ajuria, J.; Pacios, R.; Palomares, E. The effect of selective contact electrodes on the interfacial charge recombination kinetics and device efficiency of organic polymer solar cells. Phys. Chem. Chem. Phys. PCCP 2011, 13, 6105-6109.

22. Chen, C.-P.; Chen, Y.-D.; Chuang, S.-C. High-performance and highly durable inverted organic photovoltaics embedding solution-processable vanadium oxides as an interfacial hole-transporting layer. Adv. Mater. 2011, 23, 3859-3863.

23. Oh, H.; Krantz, J.; Litzov, I.; Stubhan, T.; Pinna, L.; Brabec, C.J. Comparison of various sol-gel derived metal oxide layers for inverted organic solar cells. Sol. Energy Mater. Sol. Cells 2011, 95, 2194-2199. 
24. Stubhan, T.; Oh, H.; Pinna, L.; Krantz, J.; Litzov, I.; Brabec, C.J. Inverted organic solar cells using a solution processed aluminum-doped zinc oxide buffer layer. Org. Electron. 2011, 12, 1539-1543.

25. Sun, Y.; Seo, J.H.; Takacs, C.J.; Seifter, J.; Heeger, A.J. Inverted polymer solar cells integrated with a low-temperature-annealed sol-gel-derived $\mathrm{ZnO}$ film as an electron transport layer. Adv. Mater. 2011, 23, 1679-1683.

26. Zilberberg, K.; Trost, S.; Meyer, J.; Kahn, A.; Behrendt, A.; Lützenkirchen-Hecht, D.; Frahm, R.; Riedl, T. Inverted organic solar cells with sol-gel processed high work-function vanadium oxide hole-extraction layers. Adv. Funct. Mater. 2011, 21, 4776-4783.

27. Lee, J.; Lee, K.-H.; Pugazhendi, I.; Jeong, J.K.; Kim, S.-W. Inverted polymer solar cells with an electron transport layer treated by ultraviolet light irradiation. J. Photonic Sci. Technol. 2012, 2, $22-24$.

28. Li, N.; Stubhan, T.; Luechinger, N.A.; Halim, S.C.; Matt, G.J.; Ameri, T.; Brabec, C.J. Inverted structure organic photovoltaic devices employing a low temperature solution processed $\mathrm{WO}_{3}$ anode buffer layer. Org. Electron. 2012, 13, 2479-2484.

29. Li, N.; Stubhan, T.; Baran, D.; Min, J.; Wang, H.; Ameri, T.; Brabec, C.J. Design of the solution-processed intermediate layer by engineering for inverted organic multi junction solar cells. Adv. Energy Mater. 2013, 3, 301-307.

30. Chen, S.; Manders, J.R.; Tsang, S.-W.; So, F. Metal oxides for interface engineering in polymer solar cells. J. Mater. Chem. 2012, 22, 24202-24212.

31. Meyer, J.; Hamwi, S.; Kroger, M.; Kowalsky, W.; Riedl, T.; Kahn, A. Transition metal oxides for organic electronics: Energetics, device physics and applications. Adv. Mater. 2012, 24 , 5408-5427.

32. Stadler, A. Transparent conducting oxides-An up-to-date overview. Materials 2012, 5, 661-683.

33. Minami, T. New $n$-type transparent conducting oxides. MRS Bull. 2000, 25, 38-44.

34. Bahnemann, D.W.; Kormann, C.; Hoffmann, M.R. Preparation and characterization of quantum size zinc oxide: A detailed spectroscopic study. J. Phys. Chem. 1987, 91, 3789-3798.

35. Spanhel, L.; Anderson, M.A. Semiconductor clusters in the sol-gel process: Quantized aggregation, gelation, and crystal growth in concentrated $\mathrm{ZnO}$ colloids. J. Am. Chem. Soc. 1991, $113,2826-2833$.

36. Vioux, A. Nonhydrolytic sol-gel routes to oxides. Chem. Mater. 1997, 9, 2292-2299.

37. Meulenkamp, E.A. Synthesis and growth of $\mathrm{ZnO}$ nanoparticles. J. Phys. Chem. B 1998, 102, 5566-5572.

38. Dong, W.; Dunn, B. Sol-gel synthesis and characterization of molybdenum oxide gels. J. Non-Cryst. Solids 1998, 225, 135-140.

39. Kruis Einar, F.; Fissan, H.; Peled, A. Synthesis of nanoparticles in the gas phase for electronic, optical and magnetic applications-A review. J. Aerosol Sci. 1998, 29, 511-535.

40. Ohyama, M.; Kozuka, H.; Yoko, T. Sol-gel preparation of transparent and conductive aluminum-doped zinc oxide films with highly preferential crystal orientattion. J. Am. Ceram. Soc. 1998, 81, 1622-1632.

41. Dong, W.; Dunn, B. Sol-gel synthesis of monolithic molybdenum oxide aerogels and xerogels. J. Mater. Chem. 1998, 8, 665-670. 
42. Antonelli, D.M.; Trudeau, M. Phasenumwandlungen und elektronische Eigenschaften mesoporöser Molybdänoxide mit ringförmiger Struktur (in German). Angew. Chem. 1999, 111, 1555-1559.

43. Alam, M.J.; Cameron, D.C. Preparation and properties of transparent conductive aluminum-doped zinc oxide thin films by sol-gel process. J. Vac. Sci. Technol. Vac. Surf. Films 2001, 19, 1642-1646.

44. Pacholski, C.; Kornowski, A.; Weller, H. Self-assembly of ZnO: From nanodots to nanorods. Angew. Chem. Int. Ed. 2002, 41, 1188-1191.

45. Noack, V.; Eychmüller, A. Annealing of nanometer-sized zinc oxide particles. Chem. Mater. 2002, 14, 1411-1417.

46. Pinna, N.; Wild, U.; Urban, J.; Schlögl, R. Divanadium pentoxide nanorods. Adv. Mater. 2003, $15,329-331$.

47. Fukumura, T.; Toyosaki, H.; Yamada, Y. Magnetic oxide semiconductors. Semicond. Sci. Technol. 2005, 20, 103-111.

48. Joo, J.; Kwon, S.G.; Yu, J.A.; Hyeon, T. Synthesis of $\mathrm{ZnO}$ nanocrystals with cone, hexagonal cone, and rod shapes via non-hydrolytic ester elimination sol-gel reactions. Adv. Mater. 2005, 17, 1873-1877.

49. Cheng, B.; Shi, W.; Russell-Tanner, J.M.; Zhang, L.; Samulski, E.T. Synthesis of variable-aspect-ratio, single-crystalline $\mathrm{ZnO}$ nanostructures. Inorg. Chem. 2006, 45, 1208-1214.

50. Li, B.; Xu, Y.; Rong, G.; Jing, M.; Xie, Y. Vanadium pentoxide nanobelts and nanorolls: From controllable synthesis to investigation of their electrochemical properties and photocatalytic activities. Nanotechnology 2006, 17, 2560-2566.

51. Liu, J.; Huang, X.; Li, Y.; Sulieman, K.M.; Sun, F.; He, X. Selective growth and properties of zinc oxide nanostructures. Scr. Mater. 2006, 55, 795-798.

52. Spanhel, L. Colloidal ZnO nanostructures and functional coatings: A survey. J. Sol-Gel Sci. Technol. 2006, 39, 7-24.

53. Clavel, G.; Willinger, M.G.; Zitoun, D.; Pinna, N. Solvent dependent shape and magnetic properties of doped $\mathrm{ZnO}$ nanostructures. Adv. Funct. Mater. 2007, 17, 3159-3169.

54. Wang, G.; Ji, Y.; Zhang, L.; Zhi, Y.; Gouma, P.-I.; Dudley, M. Synthesis of molybdenum oxide nanoplatelets during crystallization of the precursor gel from its hybrid nanocomposites. Chem. Mater. 2007, 19, 979-981.

55. Wang, J.; Polleux, J.; Lim, J.; Dunn, B. Pseudocapacitive contributions to electrochemical energy storage in $\mathrm{TiO}_{2}$ (anatase) nanoparticles. J. Phys. Chem. C 2007, 111, 14925-14931.

56. Niederberger, M. Nonaqueous sol-gel routes to metal oxide nanoparticles. Acc. Chem. Res. 2007, 40, 793-800.

57. Pinna, N.; Niederberger, M. Tensidfreie nichtwässrige synthese von metalloxid-nanostrukturen (in German). Angew. Chem. 2008, 120, 5372-5385.

58. Kim, W.-S.; Kim, H.-C.; Hong, S.-H. Gas sensing properties of $\mathrm{MoO}_{3}$ nanoparticles synthesized by solvothermal method. J. Nanopart. Res. 2009, 12, 1889-1896.

59. Wei, G.; Qin, W.; Zhang, D.; Wang, G.; Kim, R.; Zheng, K.; Wang, L. Synthesis and field emission of $\mathrm{MoO}_{3}$ nanoflowers by a microwave hydrothermal route. J. Alloy. Compd. 2009, 481, 417-421. 
60. Yu, X.; Xu, Z.; Han, S.; Che, H.; Yan, X.; Liu, A. Synthesis of well-ordered lamellar mesoporous molybdenum oxide. Colloids Surf. Physicochem. Eng. Asp. 2009, 333, 194-198.

61. Grote, C.; Garnweitner, G. Die nicht-wässrige sol-gel-synthese-eine alternative für die herstellung hochqualitativer metalloxid- nanopartikel (in German). Chem. Ing. Tech. 2010, 82, 615-622.

62. Pinna, N.; Karmaoui, M.; Willinger, M.-G. The "benzyl alcohol route": An elegant approach towards doped and multimetal oxide nanocrystals. J. Sol-Gel Sci. Technol. 2010, 57, 323-329.

63. Teoh, W.Y.; Amal, R.; Madler, L. Flame spray pyrolysis: An enabling technology for nanoparticles design and fabrication. Nanoscale 2010, 2, 1324-1347.

64. Tari, O.; Aronne, A.; Addonizio, M.L.; Daliento, S.; Fanelli, E.; Pernice, P. Sol-gel synthesis of $\mathrm{ZnO}$ transparent and conductive films: A critical approach. Sol. Energy Mater. Sol. Cells 2012, 105, 179-186.

65. Niederberger, M.; Pinna, N. Metal Oxide Nanoparticles in Organic Solvents: Synthesis, Formation, Assembly and Application; Springer-Verlag: London, UK, 2009; pp. 7-18.

66. Bhat, J.S.; Patil, A.S.; Swami, N.; Mulimani, B.G.; Gayathri, B.R.; Deshpande, N.G.; Kim, G.H.; Seo, M.S.; Lee, Y.P. Electron irradiation effects on electrical and optical properties of sol-gel prepared ZnO films. J. Appl. Phys. 2010, 108, 043513:1-043513:8.

67. Djurisic, A.B.; Leung, Y.H. Optical properties of ZnO nanostructures. Small 2006, 2, 944-961.

68. Morkoc, H.; Özgür, Ü. Zinc Oxide: Fundamentals, Materials and Device Technology; WILEY-VCH Verlag GmbH\&Co: Weinheim, Germany, 2009; pp. 1-70.

69. Oprea, O.; Andronescu, E.; Vasile, B.C.; Voicu, G.; Covaliu, C. Synthesis and characterization of ZnO nanopowder by non-basic route. Dig. J. Nanomater. Biostruct. 2011, 6, 1393-1401.

70. Briois, V.; Giorgetti, C.H.; Baudelet, F.; Blanchandin, S.; Tokumoto, M.S.; Pulcinelli, S.H.; Santilli, C.V. Dynamical study of $\mathrm{ZnO}$ nanocrystal and $\mathrm{Zn}-\mathrm{HDS}$ layered basic zinc acetate formation from sol-gel route. J. Phys. Chem. C 2007, 111, 3253-3258.

71. Krebs, F.C.; Thomann, Y.; Thomann, R.; Andreasen, J.W. A simple nanostructured polymer/ZnO hybrid solar cell-preparation and operation in air. Nanotechnology 2008, 19, 424013:1-424013:12.

72. Liu, Y.; Li, Y.; Zeng, H. ZnO-based transparent conductive thin films: Doping, performance, and processing. J. Nanomater. 2013, 2013, 1-9.

73. Banerjee, S.; Gopal, J.; Muraleedharan, P.; Tyagi, A.K.; Raj, B. Physics and chemistry of photocatalytic titanium dioxide: Visualization of bactericidal activity using atomic force microscopy. Curr. Sci. 2006, 90, 1378-1383.

74. Jing, L.; Li, S.; Song, S.; Xue, L.; Fu, H. Investigation on the electron transfer between anatase and rutile in nano-sized $\mathrm{TiO}_{2}$ by means of surface photovoltage technique and its effects on the photocatalytic activity. Sol. Energy Mater. Sol. Cells 2008, 92, 1030-1036.

75. Banerjee, A.N. The design, fabrication, and photocatalytic utility of nanostructured semiconductors: Focus on $\mathrm{TiO}_{2}$-based nanostructures. Nanotechnol. Sci. Appl. 2011, 4, 35-65.

76. Hammond, S.R.; Meyer, J.; Widjonarko, N.E.; Ndione, P.F.; Sigdel, A.K.; Garcia, A.; Miedaner, A.; Lloyd, M.T.; Kahn, A.; Ginley, D.S. Low-temperature, solution-processed molybdenum oxide hole-collection layer for organic photovoltaics. J. Mater. Chem. 2012, 22, 3249-3254.

77. Coutt, T.J.; Mason, T.O.; Perkins, J.D.; Ginley, D.S. Transparent Conducting Oxides: Status and Opportunities in Basic Research. In Photovoltaics for the 21st Century: Proceedings of the 
International Symposium; Kapur, V.K., McConnell, R.D., Carlson, D., Ceasar, G.P., Rohatgi, A., Eds.; The Electrochemical Society: Philadelphia, PA, USA, 1999; Volume 1999, pp. 274-286.

78. Yip, H.-L.; Jen, A.K.Y. Recent advances in solution-processed interfacial materials for efficient and stable polymer solar cells. Energy Environ. Sci. 2012, 5, 5994-6011.

79. Ecker, B.; Egelhaaf, H.-J.; Steim, R.; Parisi, J.; von Hauff, E. Understanding S-shaped current-voltage characteristics in organic solar cells containing a $\mathrm{TiO}_{x}$ interlayer with impedance spectroscopy and equivalent circuit analysis. J. Phys. Chem. 2012, 116, 16333-16337.

80. Meyer, J.; Zilberberg, K.; Riedl, T.; Kahn, A. Electronic structure of Vanadium pentoxide: An efficient hole injector for organic electronic materials. J. Appl. Phys. 2011, 110, 033710:1-033710:5.

81. Meyer, J.; Khalandovsky, R.; Gorrn, P.; Kahn, A. $\mathbf{M o O}_{3}$ films spin-coated from a nanoparticle suspension for efficient hole-injection in organic electronics. Adv. Mater. 2011, 23, 70-73.

82. Hauch, J.A.; Schilinsky, P.; Choulis, S.A.; Rajoelson, S.; Brabec, C.J. The impact of water vapor transmission rate on the lifetime of flexible polymer solar cells. Appl. Phys. Lett. 2008, 93, 103306:1-103306:3.

(C) 2013 by the authors; licensee MDPI, Basel, Switzerland. This article is an open access article distributed under the terms and conditions of the Creative Commons Attribution license (http://creativecommons.org/licenses/by/3.0/). 